\title{
Bina Vergisine Esas Rayiç Bedellerin Belirlenmesinde Yaşanan Sorunların Analizi: Kayseri İli Talas İlçesi Örneği
}

\author{
N. Iş1l Karagöz \\ Ankara Üniversitesi \\ ORCID:0000-0001-6540-4880
}

\author{
Metin Arslan \\ Ankara Üniversitesi \\ ORCID:0000-0002-5000-1226
}

\section{Öz}

Bu araştırmada Kayseri ili Talas ilçesinde bina vergisine esas rayiç bedellerin belirlenmesi sürecinde emlak vergisi uygulamalarında karşılaşılan sorunların analizi üzerinde durulmuştur. Bu sorunların analizi yapılırken; Inceleme yapılan taşınmazın fiili durumunun arsa, arazi ya da bina olup olmadığı, beyan edilen inşaat sınıfının ve bina bağımsız bölüm alanının doğruluğu, inşaat türünün, yapı ve inşaat ruhsatına göre uygunluğunun analizi yapılmış ve bu sorunlara yönelik çözüm önerileri sunulmuştur. Ayrıca bu çalışmaya tamamlayıcı katkısı olacă̆ı düşüncesiyle yoklama memurlarının karşılaşmış oldukları sorunların tespitine yönelik anket uygulanmıştır. Araştırmada tarama, doküman analizi ve yerinde inceleme yöntemi kullanılmıştır. Araştırma sonuçlarına göre, inşaat sınıfı, inşaat türü, kullanım şekli, asansör ve kaloriferin olup olmaması durumları dikkate alındığında gerçeği yansıtmayan bildirimler olduğu görülmüştür. Bu bildirimlerdeki eksiklikler ve hatalar önemli oranda emlak vergisi kayıplarına neden olmakla birlikte, adaletli bir vergi sisteminin uygulanmasın da zorlaştırdiğg görü̈lmüştür. Kayseri ili Talas ilçesinde bulunan 106 adet taşınmaz üzerinde yapılan bu araştırmada bildirim eksikliği ve hatalarından kaynaklanan yoklama öncesi ve yoklama sonrası bina vergisi kaybının \%63 civarında olduğu saptanmıştır. Çalışmada, belirlenen söz konusu sorunlara yönelik çözüm önerileri geliştirilmiştir. Bu öneriler çerçevesinde bina vergisine esas rayiç bedellerin belirlenmesinde yaşanan sorunların ortadan kaldırılması için bina vergisi belirlerken bölgeleme yöntemine geçilebilir. Bu yöntemde şehirler değer açısından belirli sayıda bölgeye ayrtlabilir. Her bölge için ayrı ayrı lüks, 1. 2. 3. ve basit inşaat sınıfları belirlenebilir. Her bir taşınmaz için bildirim sırasında belirli bir süre geçerliliği olacak yoklamanın yapılmasıyla vergi kayıplarının önüne geçilebilir. Adaletli vergilendirme, vergi kaçakların önlenme konusunda objektif değerlemenin yapılması için, gayrimenkul geliştirme ve yönetimi konusunda bilgi birikimine sahip, bu alanda uluslararası standartlar doğrultusunda eğitim almış uzman kişilere görev verilmesi kamu kurum ve kuruluşları için önem arz etmektedir.

Anahtar Kelimeler: Bina vergisi, bina sınıf tespiti, rayiç bedel, beyan sureti.

idealkent (c) Kent Araştırmaları Dergisi (Journal of Urban Studies) 


\title{
Analysis of the Problems in the Determination of Market Value Based on Building Tax: The Case of Talas District of Kayseri Province
}

\author{
N. Işıl Karagöz \\ Ankara University \\ ORCID:0000-0001-6540-4880
}

\author{
Metin Arslan \\ Ankara University \\ ORCID:0000-0002-5000-1226
}

\begin{abstract}
In this research, the analysis of the problems encountered in real estate tax applications in the process of determining the fair value of the building tax in the Talas district of Kayseri was emphasized. While analyzing these problems; the analysis of the suitability of the construction type and the building independent section area, the suitability of the construction type according to the building and construction license, and the solutions for these problems are presented. In addition, a questionnaire was applied to determine the problems encountered by the probation officers with the thought that this study would be a complementary contribution. Screening, document analysis and on-site inspections were used in the study. According to the results of the study, it was seen that there were not any reflections in terms of construction class, type of construction, usage type, elevator and whether there is heating or not. The deficiencies and errors in these declarations have resulted in significant tax loss as well as making it difficult to implement a fair tax system. In this study conducted on 106 real estate in Kayseri, Talas district, it was found that the loss of building tax before and after the polling due to lack of notification and errors was $63 \%$. In order to eliminate the problems in the determination of the market value of the building tax, the method of regionalization can be used to determine the building tax. In this method, cities can be divided into a certain number of regions in terms of value. For each region, luxury, 1, 2 and 3 simple construction classes can be determined. For each property, tax losses can be prevented by conducting the polling which will be valid for a certain period of time during the notification. It is important for public institutions and organizations to provide expert taxation in the field of real estate development and management, in order to conduct objective appraisal in the field of fair taxation, prevention of tax evasions, and experts trained in this field in accordance with international standards.
\end{abstract}

Key Words: Building tax, building class determination, market value, declarations. 


\section{Giriş}

Uzun bir tarihi geçmişe sahip olan vergi uygulamaları, kamu hizmetlerinin mali yönden giderlerini karşılamak için bireylerden yapmış oldukları iş ve işlemlerden alınan paralar olarak görülmektedir. TDK (2006)'ya göre vergi, "kamu hizmetlerine harcanmak için hükûmetin, yerel yönetimlerin yasalara göre doğrudan doğruya veya bazı malların fiyatlarının üstüne koyarak dolaylı yoldan herkesten topladığı para" olarak tanımlanmıştır. Vergi Türkiye Cumhuriyeti'nde en son 1982 Anayasası'nda belirtilen ifadeyle herkesin ödeme gücüne ve gelir miktarına göre ödemekle yükümlü olunan ödevler arasındadır. Vergi ödeme, Anayasada yer alması nedeniyle zorunlu bir ödevdir. Diğer taraftan vergiler devletin kamu hizmetlerinin giderleri için bir mali kaynak olmasının yanında devletin sosyal, ekonomik ve politik hayata etki eden bir araç olma görevini yerine getirmektedir (Dönmez, 2006). Vergi, ülke kalkınmasında yer alan önemli öğelerden biri olarak görülmektedir (Uludağ ve Turunç 2014). Vergi, devletle vatandaş arasında güçlü bir bağ oluşturması yönüyle devletlerin vaz geçemeyeceği önemli kaynaklar arasindadır. Devletler, kendinden beklenilen görev ve sorumlulukları yerine getirirken halkının refah ve mutluluk içinde yaşamasına imkânlar sunarken vergiye ihtiyaç duymaktadırlar (Kayan 2000, s. 80-87).

Emlak vergisi, tarihi geçmişi eski olan ülkelerin çoğunluğunda uygulanan, arazi, arsa ve binalar için ödenen vergi olarak bilinmektedir (B̈̈yükkaracığan, 2016, s. 148). En genel tanımıyla günümüzde emlak vergisi, gerçek ve tüzel kişilerin mülkiyetinde bulunan bina, arsa ve araziden alınan hasılatı ve yönetimi çoğunlukla belediyelere bırakılmış sürekli, objektif ve özel nitelikte bir servet vergisidir (Hacıköylüoğlu 2009, s. 1-14).

Yapılan araştırmalarda emlak vergisinin M.Ö 2000 yıllarında Çin'de daha sonraları Yunan ve Roma imparatorluklarında uygulandığı görülmüştür. Eski Yunan ve Roma İmparatorluğu'nda uygulanan verginin ağırlık noktasını taşınmazların oluşturduğu görülmüştür. Özellikle Roma' da vergi sistemi mülk gelirleri, tekeller, savaşlarda elde edilen ganimetler ve haraçlardan oluşmaktaydı. Ortaçağın sonlarında bugünkü anlamıyla modern vergilendirme sisteminin ortaya çıktı̆̆ görülmüş̧ür (Alkan, 2010).

Türkiye'de emlak vergisinin tarihi gelişimi Cumhuriyet öncesi ve Cumhuriyet sonrası olmak üzere ikiye ayrılmaktadır. Cumhuriyet öncesi dönem olan Osmanlı Devleti'nde vergiler şeri (kaynağını dinden alan) ve öşri (kaynağını padişahtan alan) vergiler olmak üzere iki şekilde uygulan- 
mıştır. Osmanlı Devleti'nde ilk kez 1804 yılında "senedi ittifak" ile padişahın vergi toplama yetkisi ayanlar ${ }^{1}$ vergi lehine sınırlandırmıştır. 1839 yılında Tanzimat Fermanı ile Padişah tek taraflı olarak vergilendirme gücünü sınırlandırmıştır. 1856 ıslahat fermanı, 1875 Adalet Fermanı ile yabancı ülkelerin baskısı ile padişah vergilendirme konusunda belli ilke ve kurallara uymayı kabul etmiştir (Hacıköylüoğlu 2009, Tarin 2013).

Türkiye Cumhuriyeti'nin kurulmasiyla birlikte ekonomik yönden zor günler geçiren ve bu zorlukların üstesinden gelinmesi amacıyla fikir arayışı amacıyla İzmir'de toplanan I. İktisat kongresinde, ekonomik bağımsızlı̆̆ı olmayan bir ülkenin siyasi bağımsızlığından söz edilemeyeceği anlayışı çerçevesinde aşar vergisinin kaldırılması ve temettü vergisinin gelir vergisine dönüştürülmesi kararı alınmıştır (Türkal 2011, s. 91). Cumhuriyet Dönemiyle birlikte Aşar Vergisi 552 Sayılı Kanun'la 17/2/1925 tarihinde kaldırılmıştır. 1929 yılı ekonomik krizinde ise tahrir değerleri on katına çıkarılmışır. 1982 tarihli Türkiye Cumhuriyeti Anayasası'nnn 73'üncü maddesi vergi konusunda gerekli görevlerin yerine getirilmesi konusunda gerekli açıklamalarına yer vermiştir. Vergi Ödevi başlıklı 1982 Anayasası'nın 73'üncü maddesinin 1'inci fıkrasında; "Herkes, kamu giderlerini karşılamak üzere, malî gücüne göre, vergi ödemekle yükümlüdür". 2'inci fıkrasında ise; "Vergi yükünün adaletli ve dengeli dağılımı, maliye politikasının sosyal amacıdır" hükümleri yer almıştır. Bu hükümler çerçevesinde, herkes, adaletli ve dengeli olarak dağılımı yapılmış ödeme gücüne göre vergi ödemekle yükümlü bulunmaktadır. Diğer bir ifadeyle anayasa, vergi kanunlarını; "genellik", "adalet", "mali güce göre vergileri alma" ve "yasallık" ilkelerine göre düzenlenmesi, uygulanması ve hazırlanmasının önemine işaret etmiştir (Kumkale 2015).

Vergiler "adalet, kesinlik, ekonomiklik, uygunluk ve yasallık" ilkelerinin özellikleri doğrultusunda belirlenmektedir. Vergi hususunda dikkat edilmesi gereken diğer bir nokta verginin asli unsuru olan vergi konusudur. Konusu belli olmayan bir vergi konulamaz ve alınamaz. Türkiye Cumhuriyeti'nde vergilendirme sisteminin uygulanması Tanzimat Dönemi'ne kadar uzansa da günümüzde uygulanan vergi türleri² ${ }^{2}$ 1924, 1961

\footnotetext{
${ }^{1}$ Osmanlılarda, bir kentin ileri gelenleri. 2-Osmanlılarda, XVIII. yüzyıldan bu yana illerin yönetiminde yetki kazanmış yerli kişiler. 3. Ayan Meclisi üyesi. http://www.tdk.gov.tr/index.

${ }^{2}$ Vergi kanunları Baş (2002) tarafından şu şekilde sıralanmıştır: 2577 Sayıl İdari Yargılama Usulü Kanunu, 213 Sayılı Vergi Usul Kanunu, 193 Sayıl Gelir Vergisi Kanunu, 5520 Sayıl Kurumlar Vergisi Kanunu, 1319 Sayıl Emlak Vergisi Kanunu, 6183 Sayılı Amme Alacaklarının Tahsil Usulü Kanunu, 2464 Sayılı Belediye Gelirleri Kanunu, 4760 Sayıl Özel Tüketim Vergisi Kanunu, 488 Sayılı Damga Vergisi Kanunu, 3065 Sayıl Katma Değer Vergisi Kanunu, 210 Sayılı Değerli Kâğıtlar Kanunu, 492 Sayılı Harçlar Kanunu, 197 Sayılı Motorlu
} 
ve 1982 anayasalarında konularına göre belirlenmiştir. Sıralanan bu vergi türleri aynı zamanda servet, gelir ve harcamalardan alınan vergi olarak da siniflandirılmaktadir.

*Gelir üzerinden alınan vergiler (Gelir Vergisi, Kurumlar Vergisi),

*Servet üzerinden alınan vergiler (Emlak Vergisi, Motorlu Taşıtlar Vergisi, Veraset ve İntikal Vergisi),

*Harcamalar üzerinden alınan vergiler (Katma Değer Vergisi, Özel Tüketim Vergisi, Gümrük Vergisi, Harçlar, Banka ve Sigorta Muameleleri Vergisi, Damga Vergisi, Özel İletişim Vergisi).

Gelir vergisi: 6/1/1961 tarihli Resmi Gazete' de yayınlanan, 10700 sayılı ve 193 numaralı Gelir Vergisi Kanunu'nun 1'inci maddesine göre gelir vergisi "gerçek kişilerin gelirleri gelir vergisine tabidir ve gelir bir gerçek kişinin bir takvim yılı içinde elde ettiği kazanç ve iratların safi tutarı" olarak tanımlanmıştır.

Emlak Vergisi: Türkiye'nin coğrafi sınırları içinde bulunan taşınmazlar (bina, arsa ve arazi) bu kanunun hükümlerine göre emlak vergisine tabidir. Emlak vergisi süreklilik arz eden bir vergi türü olup, belediyeler tarafından tahsil edilmektedir. Emlak vergisi yılda tek taksit veya iki taksit şeklinde tahsil edilmektedir. İlk taksiti mart, nisan ve mayıs aylarında, ikinci taksiti ise kasım ayında ödenmektedir. Emlak vergisi ödeme görevi taşınmaz malın tapusuna sahip olan mükellefler tarafından yapıldı̆̆ı gibi intifa hakkı sahipleri tarafından da yapılabilir. Bundan dolayı emlak vergisi dolaysız vergi türleri arasında yer almaktadır. Emlak vergisi, belediyelerin kendisinden beklenilen hizmetlerin yerine getirirken harcamış oldukları mali kaynağa temel teşkil etmesinin yanında, diğer vergi türlerinin uygulanmasında temel ölçüt olarak kullanılması bakımından da önem arz etmektedir. 2002 yılında yapılan mevzuat değişikliği ile birlikte emlak vergisinin oluşturulması ve kanuna uygun olarak uygulanması belediyelere bırakılmıştır (Türkiye Belediyeler Birliği, 2013).

\section{Literatür Taraması ve Kuramsal Temeller}

Emlak Vergisini çeşitli yönlerden ele alan sınırlı sayıda tez yapılsa da bu konuda yazılan makalelerin bolluğu bu alanda çalışmaların gittikçe önem

Taşıtlar Vergisi Kanunu, 6802 Sayılı Gider Vergileri Kanunu, 3100 Sayılı Ödeme Kaydedici Cihazlar Kanunu, 7338 Sayıl Veraset ve İntikal Vergisi Kanunu, 4962 Sayıl Vakıflara Vergi Muafiyeti Hakkında Kanun, 4306 Sayılı Eğitime Katkı Payı Alınması Hakkında Kanun, 5615 Sayılı Vergi Kanunlarını Değiştiren Kanun, 6111 Sayll Kanun. 
kazandığını göstermektedir. Emlak vergisi ile ilgili mahkeme kararları ve emlak vergisinin güncelliğini koruyarak ulusal basında yer alması bu çalışmaya tamamlayıcı katkılar sağlayacağı düşüncesiyle önemli görülmüş ve bu alanda yapılan çalışmalarla ilgili literatür taranmıştır.

\section{Literatür Taraması}

Emlak Vergisi konusu ile ilgili tezler tarandığında Gürbüz (2015) tarafından "Türk Vergi Sisteminde Emlak Vergisi Uygulaması" adlı çalışmada emlak vergisinin tarihi süreçte geçirmiş olduğu evreleri ve 1319 sayılı Emlak Vergisi Kanunu'nu diğer kanunlar ile belirli ülkeler açısından değerlendirilmesi yapılmıştır. Araştırmada 1982 Anayasası'nın 73'üncü maddesinde geçen kanunilik ilkesiyle örtüşmeyen Emlak Vergisi Kanunu'nun 22'nci maddesinin kaldırılmasının önemli olacağı, Gelir Vergisi Kanununun 103'üncü maddesinin yanlış uygulandığı, Emlak Vergisi Kanunu'nda uygulamaya konulan tahakkuk zaman aşımının işlememesi, Vergi Usul Kanunu'nun 113. ve 114'üncü maddelerindeki zaman aşımını düzenleyen hükümlerinin dışına çıkıldığı sonucuna ulaşılmıştır. Benzer bir çalışma ise Organ ve Çiftçi (2015) tarafından "Çeşitli ülke mevzuatlarında emlak vergisi: Türkiye uygulamasında ortaya çıkan sorunlar ve çözüm önerileri" başlığı altında yapılmıştır. Bu çalışmada Yerel idareler ve Emlak vergisi ilişkisi üzerinde durularak Türkiye uygulamasında yaşanan sorunları ve bu sorunlara çözüm önerileri üzerinde tartışılmıştır. Yapılan bu çalışmada, mükelleflerin vergi verme konusundaki isteksizliklerinin nedeni olarak, taşınmazlara yönelik vergi değerinin gerçek değerinden düşük ya da fazla olarak gösterildiği bu olumsuz durumu ortadan kaldırmak için değerleme yapacak kurum veya yoklama memurlarının objektif kriterler konusunda eğitimli olmalarının önemli olduğu önerilmiştir. Ayrıca, taşınmazların değerlemesinin tek bir sistem üzerinden yürütülmesinin gerekliliği ve taşınmaz değerlerinin dört yılda bir güncellenmesi ve yeniden değerleme oranlarının taşınmazların gerçek değer artışazalış oranlarını yansıtmamasının da bir sorun alanı oluşturduğu ifade edilmiştir. Tarin (2013) tarafından "Yerel yönetimlerde emlak vergisi matrahının tespiti, karşılaşılan sorunlar ve çözüm önerileri" adlı çalışmada ise Emlak Vergisi'ne konu taşınmaz değeri ile Emlak Vergisi matrahının tespitinde karşılaşılan sorunlar;

a. Vergi sistemi ve emlak vergisi ile ilgili sorunlar,

b. Emlak vergisinin toplanmasıyla ilgili sorunlar,

c. Gayrimenkul değerlemesiyle ilgili sorunlar olarak sıralanmıştır. 
Altıngöz'ün (2011) yapmış olduğu çalışmada ise, "Emlak vergisi ve belediye gelirleri içindeki payı" üzerinde durmuştur. Araştırma sonucunda Takdir Komisyonu tarafından belirlenen emlak vergisine matrah olan değerin gerçek değerin ya oldukça altında ya da oldukça üstünde olduğu, emlak vergisinde beyan esasina uygun olarak beyan vermeyenlerin tespitinde güçlükler yaşandığı, beyan verenlerden vergi alındığı beyan vermeyenlerden ise vergi alınmadığı ve bunlara yönelik ceza uygulanmadığı sonucuna ulaşılmıştır. Ayrıca bu çalışmada 5393 Sayılı Kanun doğrultusunda, belediyenin yerel yönetimler içerisindeki yeri, belediyenin gelirlerinden olan emlak vergisi ve Türkiye'de emlak vergisinin belediye gelirleri içerisindeki payı analiz edilmiştir.

Alkan (2010) tarafından yapılan "Türk vergi hukukunda emlak vergisi matrahının incelenmesi ve değerlendirilmesi" adlı çalışmada ise Emlak Vergisi'nin hangi matrah üzerinden hesaplanacağı ve bu matrahın belirlenmesinde hangi yöntemin kullanılacağı üzerinde durulmuştur. Araştırma sonucunda belirli sayıdaki mükellef grubunun sahibi olduğu taşınmazların gerçek değerleri üzerinden vergilerini öderken çoğu mükellefin ise asgari beyan değeri üzerinden vergi ödemelerinin adaletsizliklere yol açtığı ifade edilmiştir. Hacıköylü (2009) "Emlak vergisinde değerleme sorunu ve değer tespitine ilişkin öneriler" isimli çalışmasında, Emlak Vergisi'nin temelini oluşturan matrahın doğru tespit edilmesinin vergi gelirlerini artırması ve adaleti sağlamada önemli olduğu ancak ülkemizde matrahın doğru belirlenmesinde objektifliğin yakalanmadığı sonucuna ulaşmıştır. Ayrıca, şehirleşme ile başlayan süreçte taşınmaz değerlerinde artış olmasına rağmen emlak vergilerinde artış yerine azalmaların olduğu, Türkiye'de taşınmaz değerleme yapılırken çeşitli yöntemler uygulandığından farklı bedellerin ortaya çıktı̆̆ı görülmüştür.

Kırar' ın (2008) “Taşınmazlarda emlak vergisine esas değer, tapu değeri ve piyasa değeri arasındaki farklılıkların incelenmesi; Beşiktaş Örneği" adlı çalışmasında, taşınmaz değerlemesi ile ilgili temel kavramlar tanımlanmış, içeriği açıklanmış ve taşınmaz mal değerleme yöntemleri hakkında bilgi verilmiştir. Çalışmada ayrıca Emlak Vergisi değeri, tapu değeri, piyasa değeri kavramları açıklanmıştır.

Emlak vergisi değeri, tapu değeri, piyasa değeri arasındaki farklılıkların incelenmesi için seçilen Beşiktaş ilçesinde 2007 yılında satışı yapılan 60 adet taşınmazın emlak vergisi değeri ile tapu değeri arasında \%144,71 fark olduğu ve Emlak Vergisi değeri ile piyasa değeri arasında \%587,26 fark 
olduğunu gözlemiştir. Bu alanda yapılan en eski çalışmalardan birisi de Gerçel (1994) tarafından "Emlak vergisi mevzuat ve uygulamasının analizi" üzerine yapılmıştır. 1986 yılında yerel yönetimleri devredilen Emlak Vergisi'nin getirdiği sorunlar üzerinde durularak Emlak Vergisi'nin gelir artışını sağlaması düşünülmüş ancak bu durum gelir azalmasına neden olduğu için yerel yönetimlerce olumlu karşılanmadığı görülmüştür. Ayrıca Emlak Vergisi'nin alımında yoğun prosedürlerin ve uygulama güçlüklerinin olduğu görülmüştür.

Araştırmaya kaynaklık eden makaleler ve ele aldıkları konulardan bazıları ise şunlardır: Büyükkaracığan (2016) “Gayrimenkullerde emlak vergisi matrah değeri ile piyasa değeri arasındaki farklılıkların araştırılması ve Konya Meram örneği" isimli araştırmasında Meram İlçesi'nde bulunan 115 mahallenin merkezi konumunda bulunan ve değeri en fazla olan cadde-sokaklardaki parsellerin verileri üzerinde durmuştur. Yapılan değerlendirmeler sonucunda, bu farklılıkların birden çok sebebi olduğu görülmüştür. Bu sebepler ise;

a. Değerlemenin uzman kişilerce yapılmaması,

b. Arazide doğruluğunun test edilmemesi,

c. Rayiç bedellerin güncellenmelerinin yapılamaması,

d. Vergi tahsiline ilişkin sorunlar,

e. Yüksek oranlı vergiler nedeniyle mükelleflerin ödemede hassas davranmamaları şeklinde sıralamıştır.

Armağan ve Dikmen (2015) ise vergi sistemlerini diğer ülkelerle karş1laştırmalı olarak incelediği "İskandinav ülkeleri vergi sistemleri ve gelirlerinin karşılaştırmalı bir analizi" isimli çalışmalarında 1995-2013 yılları arasını kapsayan İsveç, Norveç ve Danimarka'nın vergi sistemleri ve gelirlerinin analiz edilmesini amaçlamışlardır. İskandinav ülkelerinde vergi yükü oranlarının diğer ülkelere göre daha yüksek olduğu bu durumun nedenleri arasında kişi başına düşen milli gelir seviyelerinin yüksek olmasina, sosyal refah devleti uygulamalarının yeterli olmasına ve vergi politikalarının adaletli bir şekilde uygulanması gösterilmiştir.

Yomralıŏlu ve Diğerlerinin (2011) “Dünya'da ve Türkiye'de taşınmaz değerlemesi" üzerine yapmış oldukları araştırmada Dünya'da ve Türkiye'de taşınmaz değerlemesine yönelik genel yaklaşımlar incelenmiş ve değerlemenin yasal altyapısı ile ilgili değerleme çalışmalarının genel durumu üzerinde durulmuştur. Ülkemizde halen ideal bir taşınmaz değerleme sistemi kurulamadığ1 sonucuna ulaşıldığ ifade edilmiştir. Öneri olarak taşınmaz değerleme yapılırken en büyük sıkıntı kaynağının, mevzuat 
ve yönetim olduğu ifade edilerek, bu zorlukların ortadan kalkması, adaletli vergi değerinin ve rayiç değerlerinin oluşturulması için taşınmaz değerlemesi ile ilgili nominal değerleme yöntemine göre mevzuatının yeniden düzenlenmesinin gerekliliği vurgulanmıştır.

Köktürk'ün (2009) “Taşınmaz Değerleme: Durum saptaması ve yönelimler" isimli araştırmasında taşınmaz değerleme yöntemlerinin irdelenmesi, standartlar oluşturma, yeni yöntemlerin uygulama alanları, özel taşınmaz değerleme nesneleri ve konular üzerinde durmuştur. Köktürk'ün yapmış olduğu bu çalışmada incelediği konuların, çalışmamızdaki konulara benzerlik göstermesi ve alandaki eksiklikleri tamamlayıcı olması açısindan önemli görülmüştür.

Emlak Vergisi ile ilgili mahkeme kararları ve ulusal basındaki yerine bakıldığında ise; Emlak Vergisi ile ilgili sorunların çözümü için yerel mahkemelere başvuruların yapılmasının yansıra ulusal basında da geniş yer bulduğu gözlenmektedir. Emlak vergisi konusunda gündemi meşgul eden durumlardan birisi de belediyelerce belirlenen emlak vergisi tutarı, arazi sınıf tipine olan itirazlardır. Bu itirazların ne şekilde hangi yollardan yapılacağı ise belirli kanun hükümlerine göre belirlenmiştir. Bu itirazların şekli ve emlak vergisi ile ilgili sonuçlandırılmış mahkeme kararları ulusal basında ve Resmi Gazete' de yer almıştır. 18 Ağustos 2017 tarihli Resmî Gazete'nin 30158 sayılı Tebliğinde 29/7/1970 tarihli ve 1319 sayılı Emlak Vergisi Kanunu'nun 29'uncu maddesine göre ve 29/2/1972 tarihli ve 7/3995 sayılı Bakanlar Kurulu Kararı ile yürürlüğe konulan "Emlak Vergisine Matrah Olacak Vergi Değerlerinin Takdirine İlişkin Tüzük” hükümlerinden yararlanmak suretiyle hesaplanan bedel olduğu hükme bağlanmıştır.

Bu amaçla, Emlak Vergisi'ne temel oluşturmak üzere 2018 yılında uygulanacak bina metrekare normal inşaat maliyet bedelleri Maliye Bakanlığı ile Çevre ve Şehircilik Bakanlığı'nca tespit edilmiştir. Bu tebliğe istinaden oluşturulan ve alınmaya başlanılan emlak vergileri konusunda pek çok dava açıldı̆̆ 1 görülmektedir.

Emlak Vergisi'nin haksız yere alınması ile ilgili mahkeme kararlarından bazıları ise; Danıştay Dokuzuncu Daire Başkanlığı'nın Esas No: 2005/2222 nolu ve Karar No: 2006/4411 nolu kararı ${ }^{3}$, Danıştay Dokuzuncu Daire Başkanlığının 2006/2613 Esas Numaralı, 12.12.2007 Karar Tarihli ve 2007/4945

\footnotetext{
${ }^{3}$ Danıştay Dokuzuncu Daire Başkanlığı'nın Esas No: 2005/2222 nolu ve Karar No: 2006/4411 nolu kararı. “Davacının Bursa İli, Mudanya İlçesi, Kumyaka Köyü'nde bulunan arsası için 1998, 1999 ve 2000 yılları için tahakkuk ettirilerek tahsil edilen emlak (arsa) vergisinin ret ve iadesi istemiyle yaptı̆̆ı düzeltme şikâyet başvurusu..."
} 
numaralı kararı ${ }^{4}$, Danıştay Dokuzuncu Daire Başkanlığı'nın 2006/4412 nolu karar1 ${ }^{5}$, Habertürk'ten Rahim Ak'ın haberine göre ${ }^{6}$ (7 Mayıs 2014). Feriköy Dereüstü Caddesi Elysium Cool sitesinde oturan bir vatandaş 2014'te siteleri için takdir edilen 9 bin 450 liralık metrekare birim fiyatına karşı İstanbul 9'uncu Vergi Mahkemesi'nde açılan davalar örnek gösterilebilir.

\section{Kuramsal Temeller}

Bu çalışmada tarama, doküman analizi ve yerinde inceleme yöntemi kullanılmıştır. Tarama yöntemi; geçmişte ya da inceleme yapılan anda var olan durumu olduğu şekliyle betimlemeyen, tanımlamayı amaçlayan araştırma yöntemidir (Karasar, 2002). Tarama yöntemi kullanan bir araştırmacı araştırdığı olguyu/olayı doğrudan incelemenin yanı sıra araştırdığı olgu ve olayla ilgili önceden tutulmuş kayıtları incelemeli, alanla ilgili kaynak kişilere başvurmalı ve elde edilen bilgilerle kendi gözlemlerini bütünleştirip yorum yapmalıdır.

Doküman Analizi yöntemi ise, "araştırılması hedeflenen olgu ya da olgular hakkında bilgi içeren yazılı materyallerin analizini kapsamaktadır. Dokuman incelemesi, bir araştırma problemi hakkında belirli zaman dilimi içerisinde üretilen dokumanlar ya da ilgili konuda birden fazla kaynak tarafından ve değişik aralıklarla üretilmiş dokümanların geniş bir zaman dilimine dayalı analizini olanaklı kılmaktadır" (Yıldırım ve Şimşek 2002, Karadağ, 2014). Bu çalışmada, doküman analizi yöntemi nitel araştırmaları tamamlayıcı özelliği olmasından dolayı ek bilgi kaynağı olarak kullanılmıştır.

Yerinde gözlem ve inceleme yöntemi ise duyu organları yoluyla veya duyu organlarının hassasiyetini artıran araç ve gereçlerle obje ve olayların incelenmesidir. Etkili gözlem ve incelemede sadece bakmak yeterli değil-

\footnotetext{
4 Danıştay Dokuzuncu Daire Başkanlığının 2006/2613 Esas Numaral, 12.12.2007 Karar Tarihli ve 2007/4945 numaralı kararı. "Olayda, davacının başlangıçta 3. sınıf inşaat olarak beyan ettiği dükkânları davalı idarenin 22.12.2004 tarihinde yaptı̆̆ı yoklama ile 1. sınıf inşaat grubuna girdiği tespit edilmiştir..." ${ }^{5}$ Danıştay Dokuzuncu Daire Başkanlığgı'nın $2006 / 4412$ nolu kararı. "Davacının Bursa İli, Mudanya İçesi, Kumyaka Köyü'nde bulunan arsası için 2002 yılına ilişkin olarak salınan emlak (arsa) vergisinin kaldırılması istemiyle açılan davayı; uyuşmazlı̆̆ın, davacının taşınmazının 1319 sayılı Emlak Vergisi Kanunu'nun 14. maddesine 3239 sayıl Kanunun 104. maddesiyle eklenen ( $g$ ) fikrasinda belirtilen emlak vergisi daimi muafiyetinden yararlanıp yararlanamayacă̆ına ilişkin olduğu..."

${ }^{6}$ http://www.cumhuriyet.com.tr/haber/turkiye/69101/Emlak vergisi icin dava acan kazaniyor.html\#

"Feriköy Dereüstü Caddesi Elysium Cool sitesinde oturan bir vatandaş 2014'te siteleri için takdir edilen 9 bin 450 liralık metrekare birim fiyatına karşı İstanbul 9'uncu Vergi Mahkemesi'nde açılan dava..."
} 
dir. Bunun için belirli bir amaç doğrultusunda yapılacak gözlem ve inceleme önceden hazırlanan araç gereçler vasıtasıyla dikkatlice ve sistemli bir şekilde yapılmalıdır (Tunç vd., 2006).

Emlak Vergisi Bildirimi: Emlak vergisi beyannamesinin verilmesi ve oluşturulması için, gayrimenkul satın alan kişi/kişilerin mevcut yılın sonuna kadar, yanlarında taşınmazla ilgili tapu bilgileri, malike ait kimlik bilgileri, malikin ikamet adresi ve şirketler için vergi numarası ile taşınmazın bulunduğu belediyeye başvurması gerekmektedir. Emlak vergisi beyannamesi bina, arsa ve arazi için ayrı ayrı oluşturulur.

Taşınmazın bağlı olduğu belediyelerce oluşturulan bina beyannamesi içerisinde, arsanın metrekare birim değeri, inşaatın metrekare birim maliyeti, bağımsız birimlerin brüt yüzölçümü, bina arsa alanı ve yaşı, dairenin arsa payı, inşaatın türü ve sınıfı, taşınmazın tam veya hisseli oluşu, kalorifer ya da asansör olup olmadığına dair özelliklerini içeren bilgiler bulunmaktadır. Arsa ve arazi beyannamesi içerisinde ise, arsanın metrekare birim değeri, taşınmazın tam veya hisseli oluşu ve parsel yüzölçümü bilgilerinin yanı sıra taşınmazın imara açı olup olmadığına dair bilgiler yer almaktadır.

Yoklama: Kelime anlamı olarak yoklama; herhangi bir şeyin belli bir zaman ve yerde bulunup bulunmadığını anlamak için yapılan bir eylem türü ve bir tür sayma işlemi şeklinde tanımlanmaktadır (Söyler 1987, Somuncu, 2010). Vergi hukuku açısından bakıldığında ise yoklama, vergi kanunlarının etkili bir şekilde uygulanması için gerçek durumunun tespitini gerektiren olgu ve olayların yerinde inceleme ve araştırılması işidir. Fakat yoklamanın tanımı Vergi Usul Kanununda yeterince tanımlanmamış olmasına rağmen bu kanunun 127'nci maddesinde "yoklamadan maksat" ibaresi kullanarak yoklama işleminin hangi amaçla yapılacağı belirtilmiştir. Kanunda geçen ifadeye göre; yoklamanın amacı, "mükellefi ve mükellefiyetle ilgili maddi olayları, kayıtları ve konuları araştırmak ve tespit etmek" tir (Somuncu, 2014).

Yoklama, emlak vergisi açısından, taşınmaz sahiplerinin mülkiyetinde olan mülkleri kısa zamanda kayıt altına alınmalarını sağlamanın yanı sıra mükelleflerin vergi kaçırmalarını, iş ve işlemleri gizlemelerini, vergilerini kanunlara uygun ödememeleri gibi olumsuz durumların önüne geçmesi açısından önemlidir (Tekin ve Çelikkaya, 2007). 
Bina vergisi açısından taşınmazın sınıf tespitinde yoklama memurunun gözlemleri önemlidir. Bu gözlemlerden en önemlisi yoklama memurlarının $^{7}$ öncelikle taşınmazın yerine giderek bina vergisine temel teşkil edecek olan bina inşaat sınıflarının tespitine dair cetvelde belirtilen 10 ayrı kritere uygun puanlama yaparak sinif tespitinde bulunmasıdır. Yoklama memuru puanlama yaparken kriterler arasındaki puan oranına ve ortalama (eşitlik) durumunda ise taşınmazı daima bir üst sınıf olarak belirlemektedir. Arsa ve arazi beyanları açısından ise yoklama yapmanın önemli olma nedeni, taşınmazın fiiliyatta tarımsal amaçla kullanılıp kullanılmadığının tespit edilmesidir.

\section{Bina Vergisi ve Mevzuat Hükümleri}

Bina Vergisi: Türkiye Cumhuriyeti devleti sınırları içerinde bulunan bütün binaların, bina vergisi 1319 sayılı Emlak Vergisi Kanunu hükümlerine göre tespit edilmektedir. Bina vergisinin oranı "meskenlerde binde bir, diğer binalarda ise binde ikidir". Bu oranlar, 5216 sayılı Kanunun uygulandığı büyük şehir belediye sınırları ve mücavir alanlar içinde yüzde yüz (\%100) artırımlı uygulanmaktadır. Bakanlar Kurulu bina vergi oranlarını artırma ve azaltma (yarısına kadar indirme veya üç katına kadar yükselteme) yetkisine sahiptir8.

Bina vergisinde, diğer vergilerden farklı olarak muafiyetler söz konusudur. 29 Aralık 2006 tarih ve 26391 sayılı Resmi Gazete' de yayınlanan 2006/11450 sayılı Bakanlar Kurulu Kararına göre; “1319 sayılı Emlak Vergisi Kanunu'nun 8 inci maddesinin ikinci fıkrası hükmü gereğince kendisine bakmakla mükellef kimsesi olup on sekiz yaşını doldurmamış olanlar hariç olmak üzere hiçbir geliri olmadığını belgeleyenlerin, gelirleri münhasıran kanunla kurulan sosyal güvenlik kurumlarından aldıkları aylıktan ibaret bulunanların, gazilerin, özürlülerin, şehitlerin dul ve yetimlerinin Türkiye sınırları içinde brüt $200 \mathrm{~m}^{2}$ yi geçmeyen tek meskene sahip olmaları halinde (intifa hakkına sahip olunması hali dahil), söz konusu meskene ait bina vergisi oranı, 2007 ve sonrası yıllar için sıfıra indirilmiştir"'

\footnotetext{
7 Yoklamanın amacı ve yoklama memurunun görevi Vergi Usul Kanunu'nun 127. Maddesinde şu şekilde açıklanmıştır. VUK m. 127 Maksat ve yetki: (Değişik: 4/12/1985- 3239/12 Md.). Yoklamadan maksat, mükellefleri ve mükellefiyetle ilgili maddi olayları, kayıtları ve mevzuları araştırmak ve tespit etmektir. 811/08/1970 tarih ve 13578 sayılı Resmi Gazete' de yayınlanan 1319 sayılı Emlak Vergisi Kanunu. 929 Aralı 2006 tarih ve 2639 sayılı Resmi Gazete 2006/11450 saylı Bakanlar Kurulu Karar.
} 
Bina vergisinin oluşturulmasında 15/12/1982 tarih ve 17899 sayılı Resmi Gazete' de yayınlanan "Bina İnşaat Sınıflarının Tespitine Dair Cetvel" de belirtilen kriterlerin yanında inşaat türü ve kullanım şekli özellikle dikkate alınmaktadır.

İnşaat Türünün Belirlenmesi: 1319 sayılı Emlak Vergisi Kanunu'nun 31 inci maddesinde, "Vergi değerlerinin takdirinde şehir ve köylerin tabii, iktisadi ve bölgesel şartlarına göre nazara alınacak piyasa bedeli, maliyet bedeli, kira veya yıllık istihsal değeri gibi normlar ile uyulacak usul ve esaslar, mükelleflerden ve üçüncü şahıslardan istenecek bilgiler tüzükte belirtilir" hükmü yer almaktadır. Bu hüküm gereğince yayımlanan "Emlak Vergisine Matrah Olacak Vergi Değerlerinin Takdirine İlişkin Tüzüğün" 9. maddesinde ${ }^{10}$ binaların taşıyıcı sistemleri esas alınmak suretiyle, binalar inşaat türlerine göre Çelik Karkas Binalar, Betonarme Karkas Binalar, Yığma Kâgir Binalar, Yarı Yığma Kâgir Binalar, Ahşap Binalar, Taş Duvarlı (Çamur Harçlı) Binalar, Gecekondu Tarz ve Vasfında Binalar, Kerpiç ve Diğer Basit Binalar olmak üzere sekize ayrılmıştır (Arslan 2015).

Emlak vergisinde, verginin konusu bina, arsa ve arazi gibi gayrimenkullerdir. Emlak Vergi Kanunu'nun 1'inci maddesine ${ }^{11}$ göre bina vergisinin konusu; Türkiye sınırları içinde bulunan binalardır. Emlak Vergi Kanunu'nun 12 'nci maddesine ${ }^{12}$ göre arazi vergisinin konusu ise; Türkiye s1nırları içinde bulunan arazi ve arsalardır.

1319 sayılı Emlak Vergisi Kanunu'na ${ }^{13}$ göre, Türkiye sınırları içerisinde bulunan binalar Bina Vergisine tabidir. Bina tabiri, yapıldığı madde ne olursa olsun, gerek karada gerek su üzerinde sabit inşaatın hepsini kapsar. Emlak vergisi ödemekle yükümlü kişiler, gayrimenkulünün bulunduğu bölgedeki belediyenin Emlak Vergisi birimine başvurmaları gerekmektedir.

Vergi yükümlüsünün tanımlanması: Emlak Vergi Kanunu'nun 3'üncü ve 13'üncü Maddesine ${ }^{14}$ göre mükellef; bina, arsa ve arazi gibi gayrimenkullerin sahibi, varsa intifa (başkasının malından belli kurallar içinde yararlanma)

\footnotetext{
1015/3/1972 tarihli Resmi Gazete “Emlak Vergine Matrah Olacak Vergi Değerlerinin Takdirine İlişkin Tüzük.

${ }^{11 E m l a k ~ V e r g i s i ~ K a n u n u ~ 29 / 7 / 1970 ~ t a r i h l i ~ v e ~ 13576 s a y l l ~ R e s m i ~ G a z e t e, ~ K a n u n ~ N u m a r a s ı ~} 1319$. Madde 1- Türkiye sinırları içinde bulunan binalar bu kanun hükümlerine göre Bina Vergisine tabidir. ${ }_{12}$ Madde 12 - (Değişik: 17/7/1972-1610/7 md.) Türkiye sinırları içinde bulunan arazi ve arsalar bu kanun hükümlerine göre Arazi Vergisine tabidir.

${ }_{13}^{13}$ Emlak Vergisi Kanunu 29/7/1970 Tarihli 13576Sayll Resmi Gazete, Kanun Numarası 1319.

${ }^{14}$ Madde 3 - Bina Vergisini, binanın maliki, varsa intifa hakkı sahibi, her ikisi de yoksa binaya malik gibi tasarruf edenler öder.

Madde 13 - Arazi Vergisini, arazinin maliki, varsa intifa hakkı sahibi, her ikisi de yoksa araziye malik gibi tasarruf edenler öder.
} 
hakkı sahibi, her ikisi de yoksa sahibi gibi tasarruf edenlerdir. Emlak Vergi Kanunu'nun 9'uncu maddesinde bina vergisinde mükellefiyetin başlaması ve sona ermesi ${ }^{15}$ düzenlenmiştir. Bu maddeye göre; arazi vergisinde mükellefiyetin başlaması ve sona ermesi Emlak Vergi Kanunu'nun 19. maddesinde düzenlenmiştir. Bu düzenleme de bina vergisinde yapılan düzenlemeye paralel şekilde yapılmıştır. Paralel düzenlemelere ek olarak 19'uncu maddenin 2'nci Fıkrasında şu hususlar yer almıştır: “Vergiye tabi iken muaflık şartlarını kazanan araziden dolayı mükellefiyet, bu olayın vuku bulduğu tarihi takip eden taksitten itibaren sona erer".

Vergi matrahının belirlenmesi: Vergi hukukuna göre bir taşınmazın değerlemesi, "emlak değerlemesi" olarak isimlendirilmektedir. Gelişmiş ülkeler taşınmazların değerlemesi ve yapılan bu değerlemelerin vergiye yansıtılmasına özellikle dikkat edilmektedir. Bunun gerekçesi ise emlak vergisinin özelliği gereği sıkı sıkıya emlak değerlemesine bağlı olmasıdır. Kaynaklara bakıldığında emlak vergisi doğrudan doğruya bir "değerleme vergisi" olarak ifade edilmektedir (Hacıköylü ve Heper 2010, 14).

29/7/1970 tarihli ve 13576sayılı Resmi Gazete' de yayınlanan 1319 numaralı Emlak Vergisi Kanunu'nun 7'inci Maddesinde bakıldığında vergi değeri; "bina vergisinin matrahı, binanın bu kanun hükümlerine göre tespit olunan vergi değeri" şeklinde tanımlanmıştır. Kanun'un 29'uncu maddesi ise vergi değeri hakkında düzenleme yapmıştır. Arsalar için vergi değeri; takdir komisyonlarınca arsalar için her mahalle ve arsa sayllacak parsellenmemiş arazide her köy için cadde, sokak veya değer bakımından farklı bölgeler, arazide her il veya ilçe için arazinin cinsi (kıraç, taban, sulak) itibarıyla takdir olunan birim değerlere göre, hesaplanan bedeldir"16.

Emlak Vergisi Kanunu'nun 29. Maddesinde ayrica bina, arsa ve arazi değeri için Takdir komisyonlarının görev ve sorumlulukları; “...Takdir komisyonlarının arsa ve arazilere ait birim değer tespitine ilişkin dört yılda bir yapacakları takdirler, tarh ve tahakkuk işleminin (Emlâk Vergisi Kanununun 33'üncü maddesinin (8) numaralı fıkrasına göre yapılacak takdirler dahil) yapılacağı sürenin başlangıcından en az altı ay önce karara bağlanması gerekmektedir. Arsalara ait olanlar takdirin il ve ilçe merkezlerindeki; ticaret, ziraat odalarına ve ilgili mahalle ve köy muhtarlıkları ile belediyelere imza karşılı̆̆ verilir. Araziye ait olanlar ise il merkezlerindeki ticaret ve ziraat odalarına ve belediyelere imza karşılığında verilir" şekilde ifade edilmiştir.

${ }^{15}$ Emlak Vergi Kanunu Madde 9: "Bina vergisi mükellefiyeti;

16 29/7/1970tarihli ve 13576 sayll Resmi Gazete' de yayınlanan 1319 numaralı Emlak Vergisi Kanunu 
Emlak vergisine ait bedel ve değerlerin tespiti, ilanı ve kesinleşmesi: Vergi Usul Kanunu Mükerrer 49'uncu maddesi emlak vergisine ait bedel ve değerlerin tespiti, ilanı ve kesinleşmesini düzenlemektedir ${ }^{17}$.

Değerleme ölçütlerinin oluşturulması: Değerlemede kullanılan ölçüte “değerleme yöntemi" adı verilir. Değerleme yapılırken, ilkönce değerlemenin hedefini ortaya koymak ve daha sonra da bu hedefin gerçekleşmesi için uygun bir yöntemin izlenmesi gerekir. Değerlemede kullanılan yöntemler Tanrıvermiş $(2017,298)$ tarafından yapılan şu şekilde sınıflandırılmıştır;

a. Geleneksel değerleme yöntemleri,

b. İstatistiksel veya matematiksel değerleme yöntemleri,

c. Modern/ çağdaş değerleme yöntemleri,

d. Çoğu ülkede değerleme yapılırken sıklıkla kullanılmakta olan geleneksel değerleme yöntemleridir.

Vergileme dişında tutulacak unsurların belirlenmesi: Vergileme d1şında tutulacak unsurlar, 11/08/1970 Tarihinde Resmi Gazete' de yayınlanan 1319 Nolu Emlak Vergisi ve 24/11/1994 tarihli ve 4046 sayılı Özelleştirme Uygulamaları Hakkındaki Kanunu'na göre bazı taşınmazlar bina vergisinden süresiz olarak (kiraya verilmemek şartıyla ve kanun kapsamında yapılan işletme hakkı devirleri hariç) muaf tutulmuştur.

Mevzuat Hükümleri: Emlak vergisinin mevzuat hükümlerine bakıldığında, kaynağını öncelikle Anayasa'dan aldığı görülmektedir. Türkiye Belediyeler Birliği (2013) tarafından yapılan bir çalışmada Anayasanın yanında diğer hukuki kaynaklar tablo 1'de şu şekilde sınıflandırılmıştır.

\footnotetext{
${ }^{17}$ Takdir komisyonlarının arsa ve arazilere ait birim değer tespitine ilişkin dört yılda bir yapacakları takdirler, tarh ve tahakkuk işleminin (Emlâk Vergisi Kanununun 33'üncü maddesinin (8) numaralı fikrasına göre yapılacak takdirler dahil) yapılacă̆ı sürenin başlangıcından en az altı ay önce karara bağlanması gerekmektedir. Arsalara ait olanlar takdirin il ve ilçe merkezlerindeki; ticaret, ziraat odalarına ve ilgili mahalle ve köy muhtarlıkları ile belediyelere imza karşılı̆̆ı verilir. Araziye ait olanlar ise il merkezlerindeki ticaret ve ziraat odalarına ve belediyelere imza karşılı̆̆ında verilir.
} 
Tablo 1. Emlak Vergisi'nin kaynağını oluşturan hukuki mevzuat

\begin{tabular}{|c|c|}
\hline Anayasa & Anayasa çerçevesinde uluslararası sözleşmeler \\
\hline \multirow{8}{*}{ Kanunlar } & -Emlak Vergisi Kanunu \\
\hline & - Vergi Usul Kanunu \\
\hline & - Amme Alacaklarının Tahsili Usulü Hakkında Kanun \\
\hline & - Türk Medeni Kanunu \\
\hline & - İdari Yargilama Usul Kanunu \\
\hline & - İmar Kanunu \\
\hline & - Kültür ve Tabiat Varlıklarını Koruma Kanunu \\
\hline & - Boğaziçi Kanunu ve Kat Mülkiyeti Kanunu \\
\hline \multicolumn{2}{|c|}{ Kanun hükmünde kararnameler } \\
\hline \multirow{5}{*}{ Kararlar } & - Bakanlar Kurulu Kararları \\
\hline & - Mahkeme Kararları, \\
\hline & - Anayasa mahkemesi kararları, \\
\hline & - İçtihadı Birleştirme Kararları, \\
\hline & - Diğger mahkeme kararları, \\
\hline Tüzükler & $\begin{array}{l}\text { Emlak Vergisi Kanunu'nun } 29 \text { ve 31'inci maddelerine dayanıla- } \\
\text { rak çıartılan Emlak Vergisine Matrah Olacak Vergi Değerlerinin } \\
\text { Takdirine İlişkin Tüzük }\end{array}$ \\
\hline Yönetmelikler & $\begin{array}{l}\text {-Tasarrufu Kısıtlanan Bina, Arsa ve Arazi Hakkında Yönetmelik, } \\
\text {-Planlı Alanlar Tip İmar Yönetmeliği } \\
\text {-Plansız Alanlar İmar Yönetmeliği, }\end{array}$ \\
\hline \multirow{6}{*}{ Diğer } & - Genel Tebliğler, \\
\hline & - İç Genelgeler \\
\hline & - İzahatlar, \\
\hline & - Özelgeler, \\
\hline & - Sirküler \\
\hline & - Doktrin, örf ve adetler \\
\hline
\end{tabular}

Emlak Vergisi: 29/7/1970 tarihli 13576 sayılı Resmi Gazete' de yayınlanan 1319 sayılı Emlak Vergisi Kanunu ${ }^{18}$ mevzuat hükümlerine bakıld1ğında; Türkiye sınırları içinde bulunan binalar, araziler bina ve arazi vergisine tabidir. Bina Vergisini, binanın sahibi, varsa intifa hakkı sahibi, bunlar yoksa binaya malik gibi tasarruf edenler öder. Bir binada hisse sahibi olanlar hisseleri oranında vergiye tabidir. 15/3/1972 tarihli Resmi Gazete 'de yayınlanan "Emlak Vergine Matrah Olacak Vergi Değerlerinin Takdirine İlişkin Tüzük" değerleme ölçütlerinin nasıl yapılması gerektiği 
konusuna açıllı getirmiştir ${ }^{19}$.

1319 numaralı Emlak Vergisi Kanunu'na göre Türkiye sınırları içinde yer alan binalar, araziler ve arsalar vergiye tabidir. Alınacak bu vergiler Vergi Usul Kanunu'nun 45, 49, ve 74'üncü maddeleri ve ilgili geçici maddeleri dikkate alınarak belirlenmektedir. Emlak Vergisi Kanunu'na göre bazı binalar kiraya verilmemesi şartıyla emlak vergisinden muaf tutulmuştur.

\section{Emlak Vergisinin Yerel Yönetimler Açısından Önemi}

Emlak vergisi, bina ve arazi gibi taşınmazlardan alınan bir vergi türü olmasının yanısıra çeşitli alanlar için de önem arz etmektedir. Bunlardan en önemlisi yerel yönetimler arasında bulunan belediyeler için önemli bir gelir kaynağı olmasının yanında mükellefler içinde servet ve gelir göstergesi sayılmaktadır. Vergi değeri bakımından diğer bazı hukuki işlemler için temel bir gösterge olarak kabul edilmektedir (Dönmez 2006, Tarin 2013).

Emlak vergisi, belediyelerin kamu hizmetlerini yerine getirirken giderlerini karşılamak için ihtiyaç duydukları en önemli mali kaynağı oluşturmaktadır. Yerel yönetimlerin görevleri 1982'de kabul edilen T.C. Anayasasının 127'nci maddesinde düzenlenmiştir. Ancak, görevler bu maddeyle sinırlanmamıştır. Anayasa'nın 123'üncü maddesi' nde yönetime ilişkin genel esaslar düzenlenirken "idarenin kuruluş ve görevleri merkezden yönetim ve yerinden yönetim esaslarına dayanır." ifadesiyle yönetsel içerikli yerinden yönetimden bahsedilmiş ve düzenlemeler yapılmıştır. İdare kuruluş ve görevleri açısından bir bütündür denilmiştir.

Türkiye'de yerel yönetimler "hizmet ve yer yönünden yerinden yönetim" olmak üzere 2'ye ayrılmıştır. Güneş (2010)'e göre hizmet yönünden yerinden yönetim "belli bir kamu hizmetinin merkezi idarenin dışındaki bă̆ımsız bir örgüt tarafindan yerine getirilmesi esasina dayanır. Ticaret ve sanayi odalarmın yaptıklarn işler bu kapsamdadır. Isslevsel yerinden yönetim, fonksiyonel yerinden yönetim, hizmet adem-i merkeziyeti gibi değişik şekillerde adlandırılmaktadır. Yer yönünden yerinden yönetim: Bir yöredeki ortak ve yerel nitelikteki gereksinimlerin yeterli şekilde karşılanabilmesi için, hizmeti yerine getirmekle görevli kamu tüzel kişiliklerine özerklik tanınmasıdır. Bu yönetim şekli, merkezi yönetimin malvarlı̆̆ından ayr malvarlığı, bağımsız gelir kaynakları ve bütçesi olması esasına dayanır. Belediyeler ve köy yönetimleri buna örnek gösterilebilir.

1915/3/1972 tarihli Resmi Gazete 'de yayınlanan “Emlak Vergisine Matrah Olacak Vergi Değerlerinin Takdirine İlişkin Tüzük. 
Belediyenin görevleri yasada "yerel ortak ihtiyaçlar" olarak sınırlanmış gibi görünse de son dönemlerde yasa koyucu "yerel ortak ihtiyaçların" kapsamını hayli genişletmiştir. Belediyenin imar, su, kanalizasyon, temizlik, zabıta gibi zorunlu görevlerinin yanında, sağlık tesisi, eğitim kurumu tarihi yapıların bakımı gibi isteğe bağlı görevleri de vardır. Belediyeler bu görevleri yerine getirmek için elbette çeşitli kaynaklara ihtiyaç duyarlar. Türkiye'de yerel yönetim birimlerinin gelirleri üç temel kaynağa dayanmaktadır:

a. Yerel yönetimlerin merkezi yönetim bütçe gelirlerinden aldıkları pay: Yerel yönetim birimlerinden büyükşehir belediyelerine, belediyelere ve il özel idarelerine Kanunla belirlenen oranlarda genel bütçe gelirlerinden pay ayrılmaktadır. Bu pay 2380 sayılı Kanuna göre Türkiye genelinde toplanan genel bütçe vergi gelirlerinden il, ilçe ve belde belediyelerine \%6, il özel idarelerine ise $\% 1,12$ oranında pay verilmektedir. Bu paylar, her ay Maliye Bakanlığınca, genel bütçe vergi gelirlerinden pay ayrllmayacak gelir kalemleri ve istisnalar çıkarıldıktan sonra, hesaba dâhil edilecek matraha \%6 ve \%1.12 oranları uygulanarak hesaplanmakta ve tahsilatı izleyen ayın sonuna kadar İller Bankasına aktarılmaktadır. Illler Bankası da 15 gün içinde sadece nüfus kriterini esas alarak bu payları belediyelere ve il özel idarelerine dağıtmaktadır.

b. Yerel yönetimlere merkezi yönetim tarafından yapılan transferler: Merkezi yönetimin yerel yönetimlere yaptığı transferler genel bütçe vergi gelirlerinden ayrılan paylarla sinırlı değildir. Her yıl bütçe kanunlarında yer alan belediyelere yardım koduna konulan ödenekten Maliye Bakanı tarafından ihtiyacı olan belediyelere yardım yapılabilmektedir. Ancak bütçe imkânları ile yapılan bu transferler son yıllarda içinde bulunulan ekonomik koşullar dolayısıyla oldukça sınırlı ölçüde kalmaktadır

c. Yerel yönetimlerin öz gelirleri: Belediyelerin öz gelirlerini ise harçlar, harcamalara katılım payları, ücrete tabi işler, iştirak gelirleri ve vergi gelirleri oluşturmaktadır. Bu çalışma kapsamında vergi gelirleri arasında en önemli payı alan emlak vergisi içinde bina vergisi ele alınmıştır.

Anayasa ve kanunlar dikkate alınarak taşınmaz sınıflaması ve değerleme aşamasında adaletli bir emlak vergisi oluşturmak önemlidir. Adalet ilkesine göre yapılan vergileme sisteminde, vergilerin mükellefler arasında adil ölçütlere göre dağılımı önemlidir. Vergilemede adalet ilkesini yasal olmayan yollarla zedeleyen temel faktörün vergi kaçakçılığı olduğu görülmektedir (Karg1 ve Yüksel 2010, s. 54). 


\section{Yöntemler}

Bu çalışmada tarama, doküman analizi ve yerinde inceleme yöntemi kullanılarak, Kayseri ili Talas ilçesinde bulunan 106 adet özel gayrimenkulün yoklama öncesi durumları Bina İnşaat Sınıflarının Tespitine Dair Cetvel, Beyan Sureti, Talas Belediyesi tarafından düzenlenen Emlak Yoklama Tutanağı, Yapı Ruhsat1, Yapı Kullanım İzin Belgesi, Mimari Proje, tarafımızdan beyan sureti bilgileri dikkate alınarak oluşturulan Bildirim Sureti ve Yoklama Tutanakları Verilerinin Karşılaştırmalı Analizi Tablosu ile incelenmiştir. Çalışma bulgularının objektifliğini sağlaması açısından taşınmazları yerinde inceleyen yoklama memurlarının, taşınmaz yoklaması esnasında karşılaşmış olduğu sorunlarla ilgili görüşlerini almak için yoklama memurlarına anket uygulanmiştır.

Tarama yöntemi; geçmişte ya da inceleme yapılan anda var olan durumu olduğu şekliyle betimlemeyen, tanımlamayı amaçlayan araştırma yöntemidir (Karasar 2002).

Doküman Analizi yöntemi; "araştırılması hedeflenen olgu ya da olgular hakkında bilgi içeren yazılı materyallerin analizini kapsamaktadır (Yıldırım ve Şimşek 2002, Karadağ 2014).

Yerinde gözlem ve inceleme yöntemi ise; duyu organları yoluyla veya duyu organlarının hassasiyetini artıran araç ve gereçlerle obje ve olayların incelenmesidir (Tunç 2006,56).

Bina İnşaat Sınıflarının Tespitine Dair Cetvel: Taşınmazların sınıf yapısını belirlemek için 15/12/1982 tarihli 17899 sayılı Resmi Gazete' de yayınlanmış cetveldir. Bu cetvelde binalar Lüks, Birinci sınıf, ikinci sınıf, üçüncü sınıf ve basit inşaat şeklinde beş ana kategoriye ayrılmıştır.

Beyan Sureti Bilgileri: Taşınmaza ait ada/parsel, inşaat sınıfı, bağımsız bölüm alanı, inşaat türü, kullanım şekli ve rayiç bedelini gösteren ve ilgili belediye tarafından düzenlenen belgedir. Emlak Yoklama Tutanağı: Talas Belediyesi tarafından düzenlenmiş ve üç bölümden oluşan taşınmaz ile ilgili vergiye esas teşkil edecek olan bilgilerin bulunduğu tutanaktır.

Yapı ruhsatı: Yapı ruhsatı, belediyelerin hizmet götürdüğü sınırlar içerisinde ruhsata tâbi olan, herhangi bir yapının inşaatına başlanabilmesi için belediyelerce, mücavir alan sınırları dışında ise Valiliklerce (Çevre ve Şehircilik Müdürlükleri) verilen izindir. 
Yapı Kullanma İzin Belgesi: İnşası tamamlanmış bir yapının, tamamının veya kısmen kullanılması mümkün bölümleri tamamlandığında bu bölümlerinin kullanılabilmesi için, inşaat ruhsatını veren belediye veya valiliğe bağlı il özel idaresinden alınan izin belgesidir.

Bildirim Sureti ve Yoklama Tutanaklan Verilerinin Karşılaştırmalı Analizi Tablosu: Yoklama öncesi ve yoklama sonrası ilgili belediyeye verilen beyanlardan Ada /Parsel, inşaat sınıfı, bağımsız bölüm alanı (m2), inşaat türü kullanım şekli, asansör, kalorifer, rayiç bedelleri ve yüzdelik farkları gösteren ve tarafımızdan oluşturulan tablodur.

Yoklama Memurlarına Yönelik Anket: Çalışmaya katkısı olacağı düşüncesiyle taşınmazları yerinde inceleyen yoklama memurların bu inceleme sırasında karşılaşmış oldukları problemlerle ilgili (Kişisel bilgiler, bina yoklaması esnasında kaynaklanan sorunların nedenleri, diğer ve öneriler) bilgileri içermektedir.

\section{Bulgular ve tartışma}

Bina vergisine esas rayiç bedellerinin belirlenmesinde karşılaşılan sorunların analizi sürecinde elde edilen bulgular incelenerek aşağıdaki başlıklar altında sistematik olarak tartışılmıştır.

\section{Yoklama Öncesi Bildirim Suretlerinin Analizi Sonucunda Elde Edilen \\ Bulgular}

Bina vergilerine temel oluşturan ve mükellefler tarafından ilgili belediyeye verilen 106 adet bina ve arsa beyannamelerinin yoklama öncesi durumları analiz edildiğinde, 106 adet taşınmazın 29 adedi arsa olarak beyan edildiği tespit edilmiştir. 11 adet 1 'inci sinuf betonarme bina mevcut olup bunlardan 7 adedi mesken, 2 adedi fabrika, 1 adedi idari bina, 1 adedi işyeri olduğu görülmüştür.

a. 2'nci sınıf olduğu tespit edilen 47 adet binanın, 37 adedi betonarme olup bunlardan 33 adedi mesken, 2 adedi issyeri, 1 adedi idari bina ve 1 adedi fabrikadır.

b. 3'üncü sinıf olduğu tespit edilen 18 adet binanin 12 adedi betonarmedir. Bunlardan 9 adedi mesken, 2 adedi işyeri ve 1 adedi fabrika, 3 adedi yığma mesken, 3 adedinin ise yarı yığma mesken olduğu görülmüştür. Basit inşaat sınıfında olduğu tespit edilen 1 adet mesken ise gecekondu inşaat türündedir. c. Yoklama Öncesi Bildirim Suretlerinin Analizine ilişkin bulgular değerlendirildiğinde 106 adet taşınmazın 29 adedinin arsa bildirildiği, geriye kalan 77 
adet taşınmazın ise bina olarak bildirildiği görülmüştür. Bu binalardan 11 adedi 1'inci Sınıf, 47 adedi 2'nci Sınıf, 18 adedinin 3'üncü Sınıf ve 1 adedinin ise basit sınıflı olduğu görülmüştür. 106 taşınmazın inşaat sınıfı, türü ve kullanım şekillerine göre hazırlanan ayrıntıları yoklama öncesi bildirim sureti ve yoklama tutanakları verilerinin karşılaştırmalı analizi tablo 2'de görülmektedir.

Tablo 2. Yoklama öncesi bildirim sureti ve yoklama tutanakları verilerinin karşılaştırmalı analizi

\begin{tabular}{|c|c|c|c|c|}
\hline İnşaat sınıfı & İnşaat türü & $\begin{array}{c}\text { Kullanım } \\
\text { şekli }\end{array}$ & Adet & Toplam \\
\hline \multirow{4}{*}{ 1.sinif } & Betonarme & Mesken & 7 & \multirow{4}{*}{11} \\
\hline & Betonarme & İdari bina & 1 & \\
\hline & Betonarme & Fabrika & 2 & \\
\hline & Betonarme & İşyeri & 1 & \\
\hline \multirow{7}{*}{ 2.sinif } & Betonarme & Mesken & 33 & \multirow{7}{*}{47} \\
\hline & Betonarme & İdari bina & 1 & \\
\hline & Betonarme & İşyeri & 2 & \\
\hline & Betonarme & Fabrika & 1 & \\
\hline & Yığma kâgir & Mesken & 7 & \\
\hline & Yarı Yığma & Mesken & 1 & \\
\hline & Ahşap & İşyeri & 1 & \\
\hline \multirow{5}{*}{ 3.sinif } & Betonarme & Mesken & 9 & \multirow{5}{*}{18} \\
\hline & Betonarme & İşyeri & 2 & \\
\hline & Betonarme & Fabrika & 1 & \\
\hline & Yarı Yı̆̆ma & Mesken & 3 & \\
\hline & Yığma Kâgir & Mesken & 3 & \\
\hline Basit inşaat & Gecekondu & Mesken & 1 & 1 \\
\hline Arsa & - & Arsa & 29 & 29 \\
\hline \multicolumn{4}{|c|}{ Toplam } & 106 \\
\hline
\end{tabular}

\section{Yoklama tutanaklarının analizine ilişkin oluşan yeni bildirim suret-} lerinden elde edilen bulgular

a. Yoklama memuru tarafından taşınmazın yerinde incelenmesi sonucu ortaya çıkan yoklama tutanağından sonra oluşturulan yeni bildirim suretlerinin analizi yapıldığında 106 adet taşınmazın 25 adedi 1.sınıf olup bunlardan 24 adedi betonarmedir. Bunlardan 22 adedi mesken, 3 adedi iş yeri ve 1 adedi ise ahşap meskendir.

b. 2. sınıf olduğu görülen 53 adet taşınmazın 48 adedi betonarmedir. Bunlardan 37 adedi mesken olup 11 adedi ise işyeridir. 2. Sınıf diğer taşınmazlara bakıldığından bunlardan 2 adedi yığma kâgir mesken, 1 adedi ahşap mesken ve 2 adedi ise çelikkargas işyeridir. 
c. 3.sınıf olarak belirlenen 13 adet taşınmazın 11 adedi betonarme bunlardan 7 adedi mesken ve 4 adedi işyeri, 1 adedi çelikkargas işyeri, 1 adedi yığma kâgir mesken ve 1 adedi yığma meskendir.

d. 13 adet olarak belirlenen lüks sınıfındaki taşınmazların hepsi betonarme meskendir. Basit inşaat sınıfında ise 1 adet taş duvarlı mesken olduğu belirlenmiştir.

e. Yoklama tutanaklarının analizine ilişkin yeni bildirim suretlerinin analizine ilişkin bulgular incelendiğinde 106 adet taşınmazın 19 adedi işyeri, 87 adedinin ise bina olduğu görülmüştür. Bu binalardan 22 si 1.sınıf, 40 adedi 2. Sınıf, 9 adedi 3. Sınıf, 13 adedi lüks ve 1 adedi basit inşaat türünde olduğu görülmüştür.

f. Yoklama sonrası 106 taşınmazın inşaat sınıfına göre inşaat türü ve kullanım şekillerine göre ayrıntıları, yoklama tutanaklarının analizi sonucu elde edilen bulgular ile oluşan yeni bildirim suretlerinin analizi tablo 3' de görülmektedir.

Tablo 3. Yoklama sonrası bildirim sureti ve yoklama tutanakları verilerinin karşlaştırmalı analizi

\begin{tabular}{|c|c|c|c|c|}
\hline İnşaat sınıf 1 & İnşaat türü & $\begin{array}{c}\text { Kullanım } \\
\text { şekli }\end{array}$ & Adet & Toplam \\
\hline \multirow{3}{*}{ 1.sinif } & Betonarme & Mesken & 21 & \multirow{3}{*}{25} \\
\hline & Betonarme & İşyeri & 3 & \\
\hline & Ahşap & Mesken & 1 & \\
\hline \multirow{5}{*}{ 2.sinif } & Betonarme & Mesken & 37 & \multirow{5}{*}{53} \\
\hline & Betonarme & İşyeri & 11 & \\
\hline & Yı̆̆ma Kâgir & Mesken & 2 & \\
\hline & Ahşap & Mesken & 1 & \\
\hline & Çelik Kargas & İşyeri & 2 & \\
\hline \multirow{5}{*}{ 3.sinif } & Betonarme & Mesken & 7 & \multirow{5}{*}{14} \\
\hline & Betonarme & İşyeri & 4 & \\
\hline & Çelik Kargas & İşyeri & 1 & \\
\hline & Yığma Kâgir & Mesken & 1 & \\
\hline & Yarı Yı ğma & Mesken & 1 & \\
\hline Lüks & Betonarme & Mesken & 13 & 13 \\
\hline \multirow[t]{2}{*}{ Basit inşaat } & $\begin{array}{l}\text { Taş Duvarlı } \\
\text { Basit İnşaat }\end{array}$ & Mesken & 1 & 1 \\
\hline & & & Toplam & 106 \\
\hline
\end{tabular}




\section{Yoklama Öncesi Ve Sonrası Bildirim Sureti Ve Yoklama Tutanaklarn Verilerinin Karşılaştırmalı Analizine İlişkin Bulgular}

Yoklama öncesi kayıt altına alınan bildirim sureti verileri ile yoklama sonrası idarece oluşturulan bildirim suretlerinin analizi sonucunda elde edilen bulgular;

a. Arsa: 29 adet arsanın; 22 adedi 2 sınıf bina olmuş, bunlardan $18^{\prime} \mathrm{i}$ betonarme mesken, $4^{\prime}$ ü betonarme iş yeridir. 3 adedi 3. sınıf bina olmuş 1 yığma mesken, 1 betonarme işyeri 1' i betonarme mesken. 4 adedi ise 1 'inci sınıf betonarme mesken olmuş. 1 adedi lüks bina sınıfına dönüşmüş ve betonarme mesken olarak kullanılmaktadır.

b. 1'inci Sınıf Taşınmaz: 11 adet 1 . Sınıf taşınmaz yoklama sonrası inceleme sonucunda 7 adedi lüks sinıfında betonarme mesken, 1 adedi 1.sınıftan betonarme mesken olarak 2.sınıfa indirilmiş, 2 adedi fabrikadan betonarme işyerine dönüştürlmüş, 1 adedi ise idari binadan betonarme işyerine dönüştürülmüştür.

c. 2'nci Sınıf Taşınmaz: 47 adet 2. Sınıf taşınmaz yoklama sonrası 16 adedi 1 . Sinif betonarme mesken, 1 adedi ise lük betonarme mesken olarak sınıf değişikliği yapılmıştır. Geri kalan 30 adet ikinci sınıf binalarda sınıf değişikliği olmayıp 4 adedinde asansör, kalorifer ve bağımsız bölüm alanlarında değişiklik yapılmıştır.

d. 3'üncü sınıf Taşınmaz: 18 adet 3.sınıf taşınmazdan 5 adedinde bağımsız bölüm alanı değişikliği, 1 adedi 1'inci sınıf betonarme meskene, 3 adedi 2'nci Sınıf betonarme meskene,2 adedi yarı yığmadan yığma betonarme meskene, 1 adedi betonarme işyerinden çelik kargas işyerine, 1 adedi yığma kâgirden lüks betonarme meskene, 1 adedi yığma mesken den 1'inci Sınıf ahşap meskene, 1 adet betonarme fabrikadan işyeri (benzin İstasyonu) ne, 1 adedi yarı yığmadan yığma kâgire, 1 adedi betonarme meskenden betonarme işyerine dönüştürülmüştür. Bu değişikliklerin yanı sıra 1 adet 3.sınıf yapıda asansör eklendiği görülmüştür.

e. Basit İnşaat: Yoklama öncesi 1 adet gecekondu türünde olan basit inşaat, taş duvarlı mesken olarak sınıf değişikliğinin yapıldığı görülmüştür.

f. Kalorifer ve asansör açısından bakıldığında ise az sayıda taşınmazda kalorifer ve asansör eklendiği görülmüş ve buna göre vergilendirme yapılmıştır. 


\section{Bina Yoklama İşlemlerini Gerçekleştiren Görevlilere İlişkin \\ Bulgular}

Yoklama memurlarının yoklama esnasında karşılaşmış oldukları güçlüklerle ilgili olarak uygulanan anket verilerinden kişisel bilgiler tablo 4'te verilmiştir.

Tablo 4. Yoklama memurlarına ilişkin kişisel veriler

\begin{tabular}{|c|c|c|c|}
\hline Kişisel Bilgiler & & Frekans & Yüzde (\%) \\
\hline \multirow{3}{*}{ Cinsiyet } & Erkek & 17 & 85,0 \\
\hline & Kadın & 3 & 15,0 \\
\hline & Total & 20 & 100,0 \\
\hline \multirow{4}{*}{ Eğitim durumu } & Lise & 2 & 10,0 \\
\hline & Yüksekokul & 9 & 45,0 \\
\hline & Lisans & 9 & 45,0 \\
\hline & Total & 20 & 100,0 \\
\hline \multirow{5}{*}{$\begin{array}{l}\text { Yoklama Memurluğunda } \\
\text { Geçen Süre }\end{array}$} & $1-3$ yil & 11 & 55,0 \\
\hline & $4-6$ y1l & 5 & 25,0 \\
\hline & $7-9$ yil & 3 & 15,0 \\
\hline & 10 yıl ve üstü & 1 & 5,0 \\
\hline & Total & 20 & 100,0 \\
\hline
\end{tabular}

Tablo 4 incelendiğinde ankete katılan yoklama memurlarının \%85'i erkek, \%15'inin kadın, eğitim durumlarına bakıldığında ise \%45'i lisans, $\% 45$ i önlisans ve $\% 10^{\prime} \mathrm{u}$ ise lise mezunudur. Yoklama memurluğunda geçen süre açısından bakıldığında ise yoklama memurlarının \%55'inin 1-3 yıl, \%25'inin 4-6 yıl, \%15'inin 7-9 yıl ve \%5' inin ise 10 yıl ve üstü deneyime sahip oldukları görülmüştür.

Bu tabloya göre yoklama memurlarının, genellikle erkek, lisans ve önlisans mezunları oldukları, ağırlıklı olarak 1-3 yıl arası mesleki deneyime sahip oldukları söylenebilir. Yoklama memurlarının tespit etmiş oldukları bina sınıflarına yönelik itirazlara ilişkin oranları gösterir bilgiler ise tablo 5 'te verilmiştir. 
Tablo 5. Yoklama memurlarının bina sınıflarına yönelik karşılaşmış oldukları itirazlara yönelik oranlar

\begin{tabular}{|c|c|c|c|}
\hline Sorular & & Frekans & $\begin{array}{r}\text { Yüzde } \\
(\%)\end{array}$ \\
\hline \multirow{5}{*}{$\begin{array}{l}\text { 1. Binayı lüks bina sınıfı olarak belirtilen } \\
\text { yoklama tutanağına itiraz oranı }\end{array}$} & $\mathrm{Az}$ & 1 & 5,0 \\
\hline & Orta & 4 & 20,0 \\
\hline & Çok & 4 & 20,0 \\
\hline & Sürekli & 11 & 55,0 \\
\hline & Toplam & 20 & 100,0 \\
\hline \multirow{5}{*}{$\begin{array}{l}\text { 2. Binayı 1. sınıf olarak belirten yoklama } \\
\text { tutanağına itiraz oranı }\end{array}$} & $\mathrm{Az}$ & 8 & 40,0 \\
\hline & Orta & 7 & 35,0 \\
\hline & Çok & 3 & 15,0 \\
\hline & Sürekli & 2 & 10,0 \\
\hline & Toplam & 20 & 100,0 \\
\hline \multirow{4}{*}{$\begin{array}{l}\text { 3. Binayı 2. sınıf olarak belirten yoklama } \\
\text { tutanağına itiraz oranı }\end{array}$} & Hiç & 11 & 55,0 \\
\hline & $\mathrm{Az}$ & 5 & 25,0 \\
\hline & Orta & 4 & 20,0 \\
\hline & Toplam & 20 & 100,0 \\
\hline \multirow{3}{*}{$\begin{array}{l}\text { 4. Binayı 3. sınıf olarak belirten yoklama } \\
\text { tutanağına itiraz oranı }\end{array}$} & Hiç & 19 & 95,0 \\
\hline & $\mathrm{Az}$ & 1 & 5,0 \\
\hline & Toplam & 20 & 100,0 \\
\hline \multirow{2}{*}{$\begin{array}{l}\text { 5. Binayı basit sınıf olarak belirten yoklama } \\
\text { tutanağına itiraz oranı } \\
\end{array}$} & Hiç & 20 & 100,0 \\
\hline & Toplam & 20 & 100,0 \\
\hline \multirow{4}{*}{$\begin{array}{l}\text { 6. Yoklama esnasında karşılaşılan problem } \\
\text { nedenleri }\end{array}$} & $\begin{array}{r}\text { Kanun/ } \\
\text { Mevzuat }\end{array}$ & 12 & 60,0 \\
\hline & Arazi/Yapı sahibi & 3 & 15,0 \\
\hline & Yapı içi inceleme & 5 & 25,0 \\
\hline & Toplam & 20 & 100,0 \\
\hline
\end{tabular}

Tablo 5 incelendiğinde yoklama memurlarının bina sınıflarına yönelik karşılaşmış oldukları itirazların en fazla lüks bina sınıfına yönelik olduğu görülmüştür. Yoklama memurlarının \%55'nin sürekli olarak \%20' sinin ise çoğunlukla böyle itirazlarla karşılaştıkları anlaşılmıştır.

Yoklama memurlarının 1'inci sınıf olarak belirledikleri bina yoklama tutanaklarında \%40'ının hiçbir itirazla karşılaşmadıkları, \%30'unun ise az derecede itirazla karşılaştıkları görülmüştür.

Yoklama memurlarının 2'nci (\%55) sınıf yoklama tutanaklarına yönelik itirazlarla çok az karşılaştıkları, 3'üncü (\%95) ve basit bina (\%100) sınıf tutanaklarına yönelik itirazlarla ise hemen hemen hiç karşılaşmadıkları görülmüştür. 
Yoklama memurlarının yoklama esnasında karşılamış oldukları problemlerin nedenlerine bakıldığında \%60'ının kanun ve mevzuatlardan, $\% 25$ 'inin ise yapı içinin incelenememesinden kaynaklandığı tespit edilmiştir.

\section{Tartışma ve Sonuç}

Bina vergisine esas rayiç bedellerin tespitinde yaşanan sorunların belirlenmesine yönelik olarak, Kayseri Talas ilçesi örneği üzerinde gerçekleştirilen araştırma verileri değerlendirilmiştir.

Yoklama öncesi maliklerin bildirim tutanakları ile yoklama tutanaklarına dayalı olarak oluşturulan yeni bildirim suretlerinin incelenmesi ve yoklama memurlarına uygulanan anketlerin değerlendirilmesi sonucu elde edilen veriler analiz edilerek karşılıklı olarak tartışılmış ve aşağıda yer alan sonuçlara ulaşılmıştır.

- Yoklama öncesi bildirim suretlerinin analizine ilişkin bulgular değerlendirildiğinde; 106 adet binanın bina vasfında olmasına rağmen 29 adedinin $(\% 24,6)$ arsa bildirildiği, geriye kalan 77 adet $(\% 72,7)$ taşınmazın ise bina olarak bildirim cetvelinde yer aldığ 1 görülmüştür. Bildirim cetvelinde 77 adet olarak gösterilen binalardan 11 adedinin (\%14,7) 1'inci sinıf bina, 47 adedinin (\%61) 2'nci sınıf bina, 18 adedinin (\%24) 3'üncü sınıf bina ve 1 adedinin $(\% 1,3)$ ise basit sinıf bina niteliğinde olduğu görülmüş ancak lüks bina niteliğinde bir bildirim yapılmamıştır.

- Yoklama tutanaklarına göre düzenlenen yeni bildirim suretlerinin analizine ilişkin bulgular incelendiğinde; 106 adet binanın tamamının bina vasfında olduğu görülmüştür. Bunlardan 21 adedinin (\%19,8) işyeri, 85 adedinin $(\% 80,2)$ ise konut olduğu tespit edilmiştir. Bu binalardan 13 adedinin (\%15,2) lüks, 22 adedinin (\%25,8) 1'inci sinif, 40 adedinin $(\% 47,3)$ 2 'nci sınıf, 9 adedinin $(\% 10,6)$ 3'üncü sinıf ve 1 adedinin $(\% 1,2)$ ise basit inşaat türünde olduğu görülmüştür.

- Bina vergisine esas rayiç bedellerinin belirlenmesinde binaların lüks, 1'inci, 2'nci ve 3'üncü ve basit sınıf olarak beyan edilen taşınmaz sayıların, yoklama sonrası yeni bildirimlerle karşılaştırıldığında önemli farklılıklar olduğu anlaşılmıştır.

- Yoklama öncesi 1'inci sinif binanın sayısi 7 adet iken yoklama sonrasında bu sayının 22'ye yükseldiği, 2'nci sınıf yapının 41 adetten yoklama sonrası 40 âdete, 15 adet 3'üncü sınıf yapının ise yoklama sonrası 9 âdete 
düştüğü görülmüştür. Diğer taraftan yoklama öncesi bildirim cetvellerinde lüks yapı görülmediği halde yoklama sonrası yapılan değerlemede 13 adet lüks yapının olduğu tespit edilmiştir.

- Yoklama sonrası lüks ve 1'inci sınıf binanın sayısındaki artış 2'nci ve 3 'üncü sınıf binanın sayısında azalmalara neden olmuştur. Lüks ve 1'inci sınıf bina sınıflarındaki artış rayiç bedellerin artmasını da sağlamıştır.

- Diğer taraftan yoklama öncesi arsa olarak beyan edilen taşınmazlarda ağırlıklı olarak hatalı bildirimler verildiği görülmüsstür. Yapılan yoklamalar sonucunda bu bildirimlerin genellikle lüks ve 1'inci sinıf bina bildirimlerine dönüştürüldügünü ve bu durumun da rayiç bedellerinde önemli oranda artışlar meydana gelmiştir.

- Yoklama öncesi 12 adet bağımsız bölüm alanlarının $\left(\mathrm{m}^{2}\right)$ bildiriminin eksik yapıldığ 1 tespit edilmiştir. Bu 12 adet taşınmaza ait gerçek bağımsız bölüm alanlarının $\left(\mathrm{m}^{2}\right)$ beyan edilenden daha fazla olduğunun belirlenmesi emlak vergisine esas olan rayiç bedellerinin artırılmasını sağlanmıştır.

- Yoklama öncesi 4 taşınmaza ait bildirimde asansörün ve 2 taşınmazda ise kalorifer tesisatının olmadığı belirtilmiş ancak yerinde yapılan yoklama sonucunda bu taşınmazların asansörlü ve kaloriferli olduğu görülmüştür. Bu durum kısmi olarak rayiç bedellerinde artış sağlamıştır.

- Yoklama öncesinde 12 adet olarak gösterilmiş olan işyeri sayısının, yapılan yoklamalar sonucunda 21 adet olduğu görülmüştür. Kullanım şeklinin değişmesinden kaynaklı olarak rayiç bedellerde artış sağladığı görülmüştür.

- Yoklama memurlarının yoklama esnasında karşılamış oldukları problemlerin nedenlerine bakıldığında \%60'ının kanun ve mevzuatlardan, \%25'inin ise yapı içinin incelenememesinden kaynaklandığı tespit edilmiştir.

Sonuç olarak inşaat sınıfı, inşaat türü, kullanım şekli, asansör ve kaloriferin olup olmaması durumuna göre verilen bildirimlerin gerçeği yansıtmayan bildirimler olduğu anlaşılmaktadır. Yukarıda detaylı bir şekilde tartışılarak ifade edilen bildirimlerdeki eksiklik ve hataların önemli ölçülerde emlak vergisi kayıplarına neden olduğu görülmektedir. Kayseri ili Talas ilçesinde bulunan 106 adet taşınmaz üzerinde yapılan bu araştırmada bildirim eksikliği ve hatalarından kaynaklanan bina vergisi kaybının yaklaşık olarak \%63 civarında olduğu görülmektedir. 


\section{Öneriler}

Maliye Bakanlığı ile Çevre ve Şehircilik Bakanlığg'nca tarafından her yıl yayınlanan "Bina İnşaat Maliyet Bedelleri Cetveli” nde her bir inşaat sınıfı için belirlenen inşaat maliyet bedellerinin sınıflar arasında yaklaşık \%50 oranında farklılık göstermesinde kaynaklı olarak rayiç bedellerinde önemli ölçülerde değişmektedir. Bu değişiklik özellikle lüks inşaat sınıfı ve 1'inci sinif olarak belirlenen binalarda daha fazla itiraza sebep olmaktadır. Bu durumun önüne geçilmesi için inşaat sınıfları arasındaki maliyet bedellerinin kademeli olarak artırılması ile ilgili mevzuat değişikliği yapılabilir.

Bina vergisi belirlerken bölgeleme yöntemine geçilebilir. Bu yöntemde şehirler değer açısından belirli sayıda bölgeye ayrılabilir. Her bölge için ayrı ayrı lüks, 1. 2. 3. ve basit inşaat sınıfları belirlenebilir. Böylece konumlar dikkate alınarak adaletli bir sinıflamaya bağlı olarak vergilendirme sağlanmış olur. Kulanım şekillerine göre bina sınıfları kendi arasında alt kategorilere ayrılabilir. Örneğin meskenler için ayrı, işyerleri için ayrı lüks, 1'inci 2'nci 3'üncü ve basit sinfflar şeklinde kategorize edilebilinir. Böylece işyeri ve mesken arasındaki vergi oranları farklılıkları giderilerek adaletli bir vergilendirme yapılmış olur.

Her bir taşınmaz için bildirim sırasında belirli bir süre geçerliliği olacak yoklamanın yapılmasıyla vergi kayıplarının önüne geçilebilir. Bu amaçla vergi kayıplarının önlenmesi için ilçe genelindeki bütün yapılar yerinde yoklama yöntemiyle tekrar incelenebilir. Yoklama memurlarının seçimi sırasında konusunda uzman kişiler olmasına azami dikkat gösterilmelidir.

Adaletli vergilendirme, vergi kaçaklarını önlenme konusunda objektif değerlemenin yapılması için, gayrimenkul geliştirme ve yönetimi konusunda bilgi birikimine sahip, bu alanda uluslararası standartlar doğrultusunda eğitim almış uzman kişilere görev verilmesi kamu kurum ve kuruluşları için önem arz etmektedir. 


\section{Extended Abstract}

\section{Analysis of the Problems in the Determination of Market Value Based on Building Tax: The Case of Talas District of Kayseri Province}

\author{
N. Işıl Karagöz \\ Ankara University \\ ORCID:0000-0001-6540-4880
}

\author{
Metin Arslan \\ Ankara University \\ ORCID:0000-0002-5000-1226
}

This study focuses on the analysis of the problems that are encountered in the application of property tax during the process of determination of current values of building tax in the Talas district of city of Kayseri. In the examination of these problems, analyses were carried out to identify whether actual state of the estate that is under investigation a plot, a land or a building, whether the declared construction type and building independent section were in fact correct, and whether the construction type matched the building license; then solutions were presented to these problems. Additionally, a questionnaire was applied to determine the problems that inspection officers face since it was hoped that this questionnaire would be supplementary to the study.

In this study, the state of 106 private real estate property before the inspection in the Talas district of city of Kayseri was examined by studying the Scale for Determination of Building Construction Types, the Form of Declaration, the Warrant for Property Inspection prepared by the municipality of Talas, the Construction Permit, the Occupancy Permit, the Architectural Project, the Comparative Analysis Table for the Form of Declaration and Warrant of Inspection that the researchers prepared by investigating the information on forms of declarations in methods of surveying, document analysis and physical site visit. In order to ensure the objectivity of the findings, a questionnaire was administered to identify the thoughts of inspection officers on the problems that they encounter as they inspect estates. 
Tax, as it is lastly defined in 1982 constitution of the Republic of Turkey, is one of responsibilities of Turkish citizens that they need to pay to the government based on their solvency and income. Property tax is known to be a tax that people pay in most of the countries that have a long history for plots, lands and buildings. To set the base for Property Tax, Ministry of Finance along with Ministry of Environment and Urban Planning established the construction costs per square meter that was to be used in 2018. The subject of property tax is estates such as buildings, plots and lands. According to the first item of Real Estate Tax Law, building tax involves buildings in the borders of Turkey. According to the twelfth item of Real Estate Tax Law, land tax involves plots and lands in the borders of Turkey.

According to Real Estate Tax Law (Law No.1319), buildings in the borders of Turkey are subject to Building Tax. The concept of building encompasses stationary buildings either on land or on water no matter what type material was used in the construction. Persons are required to apply to property tax office of municipality where their estate is located.

Property tax constitutes the most important income for municipalities to meet their needs as they do public service. The duties of local authorities are identified in the $127^{\text {th }}$ item of the Constitution of the Republic of Turkey enacted in 1982. However, these duties include more than what has been defined in the item 127. In the $123^{\text {rd }}$ item of the Constitution to organize rudiments relating to administration, it is stated that "the establishment and duties of administration are based on rudiments of central administration and local administration," which mentions as well organizes administrative local administration. In the same item, it is also stated that administration is a whole in terms of its establishment and duties.

Building tax is calculated in accordance to decrees of Real Estate Tax Law No. 1319 for all the buildings in the border of Republic of Turkey. Building tax is "one in thousandth for residence buildings, two in thousandth for other buildings." These rates are applied with an increase of one hundred percent within the limits of metropolitan municipalities and municipal adjacent areas where the Law No. 5216 is effective. The Cabinet has the authority to increase or decrease (decreasing to half or increasing three times) building taxes.

The findings of this study where the aim was to identify problems in determination of current values of building tax in Talas district of city of Kayseri demonstrate that 29 of $106(24.6 \%)$ buildings are in fact land although they are declared as buildings while the remaining 77 estates are buildings in the form of declaration. Eleven of 77 (14.7\%) buildings that 
are listed as buildings in the form of declaration are first grade buildings, 47 of them (61\%) are second grade buildings, 18 of them (24\%) are third grade buildings and 1 of them (1.3\%) is a simple building whereas there are no buildings in the luxury grade. According to findings related to analysis of new warrants of notification based on inspection warranties, all of the 106 buildings are characteristically buildings. Twenty-one of these $(19.8 \%)$ are workplaces, 85 of them $(80.2 \%)$ are residence buildings. Thirteen of these buildings (15.2\%) are luxury buildings, 22 of them (25.8\%) are first grade, 40 of them (47.3\%) are second grade, 9 of them (10.6\%) are third grade and 1 of them $(1.2 \%)$ is a simple building.

The findings also demonstrate that the number of first grade buildings was 7 prior inspection and it increased to 22 after it; the number of second grade buildings decreased to 40 from 41 after inspection; the number of third grade buildings decreased to 9 from 15 after inspection. On the other hand, there were no luxury buildings in Forms of Declaration before inspection and it increased to 13 after the inspection.

The increase in the number luxury and first grade buildings has led to a decrease in the number of second and third grade buildings after the inspection. This increase in the number of luxury buildings has also led to an increase in the current values in the luxury and first grade buildings. Besides, it was seen that the estates that were declared as land before the inspection were mostly false declarations. As a part of the inspections, these declarations were transformed to luxury and first grade type buildings, which in the end led to an increase in the current values.

The analysis of the data yield that declarations in terms of construction grade, building type, type of use, existence of elevators and heaters were in fact faulty declarations. It can be seen that the faults and mistakes in the declarations that were discussed to a length above leads to significant lose in property taxes. As a part of this study on 106 estates in Talas district of Kayseri, it was also concluded that the property lac loss was $63 \%$ due to faults and mistakes in declarations. A suggestion to prevent such loses would be adapting a zoning method to determine property tax. With this method, cities can be grouped under different zones based on their value. Then luxury, first, second, third and simple building grades can be identified for each zone. In this way, a fairer taxing would take place by taking the locations into considerations. Moreover, subgroups can be created for building grades based on their type of utilization. For example, luxury, first, second, third and simple subcategory grades can be created for both 
residence buildings and workplaces. Thus, a fairer taxing system would be used by getting rid of the tax difference between residence and workplace buildings.

Tax loss could be prevented with an inspection that can hold true for a while during declaration for each estate. For this purpose, all the buildings district-wide can be re-inspected with physical site visits to prevent tax loss. Great care should be paid to make sure inspection officers are experts in the field.

It is of upmost importance that government agencies employ experts who are trained with respect to international standards and who have experience in estate development and management to ensure that objective evaluations are carried out to have fair taxes and to prevent tax loss.

\section{Kaynakça/References}

Alkan, M. (2010). Vergi hukuku bilim dah Türk vergi hukukunda emlak vergisi matrahınin incelenmesi ve değerlendirilmesi. Yayınlanmamış yüksek lisans tezi, Gazi Üniversitesi, Ankara.

Altıngöz, S. (2011). Emlak vergisi ve belediye gelirleri içindeki payı. Yayınlanmamış yüksek lisans tezi, Pamukkale Üniversitesi, Denizli.

Armağan, R. ve Dikmen, S. (2015). İskandinav ülkeleri vergi sistemleri ve gelirlerinin karşılaştırmalı bir analizi. AKÜ İ̈BF Dergisi, 17 (2). 67-81. DOI NO 10.5578/jeas.10158.

Arslan, M. (2015). Yapı teknolojileri -1. Ankara: Seçkin Yayınevi.

Baş, H. H. (2012). Vergi Kanunları. İstanbul: Beta Yayınları.

Büyükkaracığan, N. (2016). Gayrimenkullerde emlak vergisi matrah değeri ile piyasa değeri arasındaki farklılıkların araştırılması ve Konya Meram örneği. Selçuk Üniversitesi Sosyal ve Teknik Araştırmalar Dergisi, 11, 143-157.

Demircan, E.S. (2003). Vergilendirmenin ekonomik büyüme ve kalkınmaya etkisi. Erciyes Üniversitesi İktisadi ve İdari Bilimler Fakültesi Dergisi, 21, 97-116.

Dönmez, R. (2006). Türk vergi sistemi (4. Baskı). Eskişehir: Anadolu Üniversitesi Açık Öğretim Fakültesi, Yayın No: 828.

Gerçel, H. (1994). Emlak vergisi mevzuat ve uygulamasının analizi. Yayınlanmamış yüksek lisans tezi. Hacettepe Üniversitesi, Ankara.

Güneş, İ. (2000). Yerel yönetimler ve yerel yönetimlerin varlık nedenleri. Prof. Dr. Adnan Tezel'e Armağan, Marmara Üniversitesi i.I.̇.B.F. Dergisi, 13(1), 271-292.

Gürbüz, S. (2015). Türk vergi sisteminde emlak vergisi uygulaması. Yayınlanmamış yüksek lisans tezi. Dokuz Eylül Üniversitesi, İzmir.

Hacıköylü, C. (2009). Emlak vergisinde değerleme sorunu ve değer tespitine ilişkin öneriler. Yayınlanmamış doktora tezi. Eskişehir Anadolu Üniversitesi, Eskişehir.

Hacıköylü, C. ve Heper, F. (2010). Emlak vergisinde matrah tespitine ilişkin sorunlar ve çözüm önerileri. Maliye Dergisi, 158 (1), 1-14. 
Karadağ, R. (2014). Okuma ilgisi, tutumları ve alışkanlığı konusunda yapılmış çalışmaların lisansüstü tezlere dayalı analizi: YÖK ve proquest veri tabanları örneklemi. Pamukkale Üniversitesi Ĕ̆itim Fakültesi Dergisi, 35 (I), 1-17.

Karasar, N. (2002) Bilimsel araştırma yöntemi, Ankara: Nobel Yayıncılık.

Kargı, V. ve Yüksel, C. (2010). Maliye araştırma merkezi konferansları, İstanbul Üniversitesi İktisat Fakültesi, 54(1). 29-30.

Kayan, A. (2000). Verginin tarihsel gelişimi ve sebep olduğu bazı önemli olaylar, Maliye Dergisi, 135, 80-87.

Kırar, B. (2008). Taşınmazlarda emlak vergisinde esas değer, tapu değeri ve piyasa değeri arasındaki farklılıkların incelenmesi; Beşiktaş örneği. Yayınlanmamış Yüksek lisans tezi. İstanbul Teknik Üniversitesi, İstanbul.

Kırışık, F. ve Sezer, Ö. (2006). Türk Anayasaları'nda yerel yönetimler. Çağdaş Yerel Yönetimler Dergisi,15(2), 5-30.

Köktürk, E. (2009). Taşınmaz değerleme: durum saptaması ve yönelimler. TMMOB Harita ve Kadastro Mühendisleri Odası 12. Türkiye Harita Bilimsel ve Teknik Kurultayı 1115 Mayıs, Ankara.

Kumkale, R. (2015). Vergi adaleti. 09.10.2017 tarihinde https://www.dunya.com/kose-yazisi/ vergi-adaleti/23286 http://kararara.com/danistay/vd/danitay6388 Adresinden erişilmiştir.

Organ, İ. ve T. E. Çiftçi. (2015). Türkiye'de emlak vergisi uygulamasından kaynaklanan sorunlar ve çözüm önerileri. Niğde Üniversitesi İ̈BF Dergisi, 8(4), 127-147.

Somuncu, A. (2014). Yaygın ve yoğun vergi denetimi: hukukî yapı ve uygulamanın değerlendirilmesi. Erciyes Üniversitesi İktisadi ve İdari Bilimler Fakültesi Dergisi, 43(1),133-173.

Söyler, İ. (1987). Türk vergi hukukunda yoklama. Ankara: Maliye Gümrük Bakanlığ1 APK Yayını.

Tanrıvermiş, H. (2017). Gayrimenkul değerleme esasları. SPL Sermaye Piyasası Lisanslama Sicil ve Eğitim Kuruluşu, İstanbul.

Tarin, E. (2013). Yerel yönetimlerde emlak vergisi matrahının tespiti, karşılaşılan sorunlar ve çözüm önerileri. Yayınlanmamış yüksek lisans tezi. İstanbul Aydın Üniversitesi, İstanbul.

Tekin, F. ve Çelikkaya, A. (2007). Vergi Denetimi. Ankara: Seçkin Yayıncllık.

Tunç, M., Agalday, H. (2006). Illköğretim fen ve teknoloji 6. sinıf öğretmen kılavuz kitabl, öğretmen kılavuz kitabı. Ankara: MEB Yayınları,

Türk Dil Kurumu. (2006). Türkçe Sözlük. http://www.tdk.gov.tr Erişim Tarihi: 08.11.2017.

Türkal, H. (2011). Türkiye'de 1923-1930 yılları arası bütçe politikası ve uygulamasının vergi politikası ve uygulaması acısından değerlendirilmesi. Amme İdaresi Dergisi, 44 (3), 85-107.

Türkiye Belediyeler Birliği (2013). Temel belediye mevzuatı. Ankara: Azim Matbaası.

Uludağ, A.ve Turunç, S. (2014). Vergi ve kalkınma uluslararası toplumun gelişmekte olan ülkelere yaklaşımı. Ankara: Avrupa Birliği ve Dış İlişkiler Dairesi Başkanlığı Yayınlari.

Yıldırım, A. ve Şimşek, H. (2002). Sosyal bilimlerde nitel araştırma yöntemleri. Ankara: Seçkin Yayıncilik. 
Yomralıŏlu, T., Nişancı, R., Çete, M., Candaş, E. (2011). Dünya' da ve Türkiye' de taşınmaz değerlemesi. Türkiye'de Sürdürülebilir Arazi Yönetimi Çalıştayı, 26-27 Mayıs 2011, Okan Üniversitesi.

Nafiye Işıl Karagöz: 1979 Kayseri de doğdu. İlk, orta ve Lise eğitimini Kayseri'de tamamladı. 1998 yılında Erciyes Üniversitesi Kayseri Meslek Yüksekokulu Makine Bölümünü, 2003 yılında Erciyes Üniversitesi Fen Edebiyat Fakültesi Biyoloji Bölümünü bitirdi. 2015 yılında Ankara Üniversitesi Fen Bilimleri Enstitüsü Gayrimenkul Geliştirme Ve Yönetimi bölümünde yüksek lisansına başladı. 2003-2004 eğitim öğretim yılında özel bir dershanede Biyoloji Öğretmenliği yaptı. 2006 Yılından itibaren Kayseri Melikgazi Belediyesinde çalışmaya başladı halen bu görevini sürdürmektedir.

She was born in 1979 in Kayseri. She completed her primary, middle and high-school education in Kayseri. She graduated from Erciyes University, Kayseri Vocational School for Higher Education, Machine Department in 1998 and from Erciyes University, Faculty of Natural Sciences, Department Biology in 2003. She commenced her master studies at Ankara University, the Graduate School of Natural and Applied Sciences, the Department of Real Estate Development and Management in 2015. During 2003-2004 academic year she worked as a Biology teacher in a private teaching institution. She began working at Melikgazi Municipality in Kayseri in 2006. She still holds this position to date.

E-mail: nisilkaragoz@gmail.com

Prof. Dr. Metin Arslan: 1949 yılında Samsun'da doğdu. İlk, orta ve lise öğretimini Samsun' da tamamladı. Lisansını Ankara Erkek Teknik Yüksek Öğretmen Okulu yapı eğitimi bölümünde tamamladı. Yüksek lisans ve doktorasını Gazi Üniversitesi Fen bilimleri Enstitüsü Mimarlık Anabilim dalında yaptı. 2002 de Doçent, 2011 de Profesör oldu. Halen Ankara Üniversitesi Fen Bilimleri Enstitüsü Gayrimenkul Geliştirme Ve Yönetimi bölümünde görev yapmaktadır.

He was born in 1949 in Samsun. He finished his primary, middle and high-school education in Samsun. He completed his undergraduate studies in the Construction Department of Ankara Boys' Technical Teacher Training School. He finished his master and doctorate in Architecture Division of Institute of Natural Sciences of Gazi University. He became an associate professor in 2002, a full professor in 2011. Currently, he works in the Department of Real Estate Development and Management in the Graduate School of Natural and Applied Sciences at Ankara University.

E-mail: metinarslan@ankara.edu.tr 